\title{
Review Article \\ Recent Investigations of Phase Change Materials Use in Solar Thermal Energy Storage System
}

\author{
Qianjun Mao (D), Ning Liu, and Li Peng \\ School of Urban Construction, Wuhan University of Science and Technology, Wuhan 430081, China \\ Correspondence should be addressed to Qianjun Mao; maoqianjun@163.com
}

Received 25 March 2018; Accepted 25 June 2018; Published 12 December 2018

Academic Editor: Giorgio Pia

Copyright (C) 2018 Qianjun Mao et al. This is an open access article distributed under the Creative Commons Attribution License, which permits unrestricted use, distribution, and reproduction in any medium, provided the original work is properly cited.

\begin{abstract}
Solar thermal energy storage (TES) is an efficient way to solve the conflict between unsteady input energy and steady output energy in concentrating solar power plant. The latent heat thermal energy storage (LHTES) system is a main method of storing thermal energy using phase change materials (PCMs). Thermal properties, that is, melting points and latent heat, are the key parameters of PCMs for the TES system. In this paper, the PCMs are classified into inorganic and organic by the chemical composition, and according to the melting point, the inorganic PCMs can be divided into three contributions: low-temperature heat storage (less than $120^{\circ} \mathrm{C}$ ), medium-temperature heat storage $\left(120-300^{\circ} \mathrm{C}\right.$ ), and high-temperature heat storage (more than $300^{\circ} \mathrm{C}$ ). The present article focuses mainly on the recent investigations on the melting point and latent heat of PCMs via DSC setup in the solar TES systems. The results can provide a good reference for the selection and utilization of PCMs in the solar TES systems.
\end{abstract}

\section{Introduction}

With the essential increasing in energy consumption, energy shortage and environmental problem including tremendous demand and insufficient supply have been vital points that affect the economic development all over the world. The governments of many countries stimulate development of energy-saving technologies based on utilization of renewable energy sources [1]. Among various forms of energy, widespread thermal energy is abundantly available, such as solar radiation and geothermal energy, due to its convenience, high efficiency, and the value of direct utilization compared with other resources [2-4]. And the unpredictability of the output of renewable energy systems demands reliable and efficient energy storage units. Therefore, thermal energy storage (TES) technology plays a significant role in utilizing the renewable resources $[5,6]$. There are mainly two types of TES systems of sensible storage systems and latent storage systems, and the latent heat thermal energy storage (LHTES) system is an effective way of storing thermal energy [7]. Remarkably, phase change materials (PCMs) are latent heat storage materials, and the thermal energy transfer occurs when a material changes from solid to liquid or liquid to solid which is called the phase transition process. Initially, the thermal performances of PCMs are similar to conventional (sensible) storage materials which absorb heat with the increase of temperature in PCMs, and then PCMs absorb and release heat at a nearly constant temperature compared with the conventional storage materials $[8,9]$. Therefore, the PCM is currently seen as one of the most promising to research the TES system.

In past four decades, there were wide researches on the TES system. Some review articles have a summary in the open literatures, which focus on as follows: TES system design methodologies and the factors [10]; the materials and heat transfer performance enhancement techniques of LHTES [11, 12]; the materials, heat transfer, and phase change problem for LHTES [13]; residential scale systems for seasonal storage of solar thermal energy [14]; TES technologies using PCM capsules [5]; CFD (Fluent) software applications in LHTES [15]; PCMs for high-temperature TES system [1]; microencapsulation PCMs for TES [16]; thermal stability of PCM [17]; the preparation, thermal properties, and applications of shape-stabilized thermal energy storage materials [18]; mathematical modeling on LHTES [19]; passive LHTES system to building's energy 
performance [20]; storage materials and thermal performance enhancement for high-temperature phase change thermal storage systems [21]; thermal conductivity enhancement of PCM [2]; thermal conductivity enhancement of nanostructure of PCM [3]; the PCMs and different applications of TES [8]; metal hydride material-based thermochemical hydrogen storage [22]; the TES for power generation [7, 23]; chemical heat storage [24]; three available technologies for seasonal heat storage (sensible heat storage, latent heat storage, and chemical storage) [25]; the types of solar collectors [26]; thermochemical heat storage [27, 28]; the thermal reliability, heat storage durability, and thermal stability of cross-linked form-stable PCMs [29]; nanomaterials used base fluid to enhance thermophysical properties [30]; $\mathrm{SrBr}_{2} \cdot 6 \mathrm{H}_{2} \mathrm{O}$ as a potential material for lowtemperature energy storage systems and building applications [31]; molten alkali nitrates used as heat transfer fluid (HTF) [32]; various solar collectors and parabolic tough collector (PTC) [33]; specific heat of nanofluids [34]; the HTF for concentrating solar power (CSP) systems [35]; the practical applications, thermal properties, and configurations of PCMs [36]; the geometrical configurations of TES for CSP plant [37]; and inorganic PCMs for TES systems [38].

However, the review of thermal properties (melting point and latent heat) of PCMs with DSC is limited in the previous works. In order to gain the detailed summary of the melting point and latent heat with PCMs in the TES systems, the present paper focuses mainly on the recent investigation of the melting point and latent heat via DSC in the TES systems. According to the chemical composition, the PCMs are classified into inorganic and organic. And based on melting point, the PCMs can be divided into three contributions: low-temperature heat storage (less than $120^{\circ} \mathrm{C}$ ), medium-temperature heat storage $\left(120-300^{\circ} \mathrm{C}\right)$, and hightemperature heat storage (more than $300^{\circ} \mathrm{C}$ ). This can provide a theoretical guidance in future for selecting the more suitable PCMs in the investigations of the thermal performance for TES applications.

\section{Thermal Properties of PCMs with DSC}

2.1. DSC Setup. Differential scanning calorimetry (DSC) is an analytical method for measuring the energy difference between a sample and a reference with temperature at a programmed temperature. Therefore, the DSC system is the most commonly used approach for the study on the thermal properties of the PCMs such as the melting and freezing temperatures, the specific heat, and the latent heat [39]. According to the measuring principle, it can be divided into heat-flux DSC and power compensation DSC. For the heat-flux DSC, the temperature difference of the sample and reference can be measured accurately, which can be translated into heat-flux signals [40]. And compared with differential thermal analysis (DTA), the determination of DSC is more accurate and the reproducibility and resolution are better. Therefore, DSC has been widely used in the field of polymers, and some DAT applications can be replaced by DSC measurement with the high accuracy and sensitivity and less sample dosage. According to the DSC curves, the thermal properties including melting point and latent heat of PCMs can be investigated.

2.2. Thermal Properties of PCM. The selection of PCM for TES application depends on different factors, and the PCMs must present desirable properties that are associated with the thermodynamic, kinetic, chemical, and economics. Suitable PCMs need some thermal properties such as suitable melting point, high latent heat, high thermal conductivity, high heat capacity, and high specific heat [38]. Especially, the melting point of the material must be equal or similar to the operating temperature on some applications. The latent heat should be as high as possible, in particular, on a volumetric basis to minimize the size of the thermal energy storage device. Consequently, it is extremely significant to study the melting point and the latent heat of PCMs.

Based on the large quantity investigations, there were a lot of works to research the thermal properties of PCMs with DSC. In general, PCMs are classified into organic and inorganic materials. Organic materials consist of paraffin and nonparaffin such as fatty acids, while inorganic materials comprise salt hydrates, saline composites, and metallic alloys [11]. In this paper, according to the melting point and latent heat, the PCMs including inorganic material, organic material, and the three types of inorganic PCM based on the phase change temperature have been reviewed.

\section{Recent Investigations of PCMs with DSC}

\subsection{Inorganic Materials}

3.1.1. Low-Temperature PCMs. Low-temperature PCMs have the low-melting point $\left(<120^{\circ} \mathrm{C}\right)$, which was appropriate for TES in building' application and CSP plant. Many researchers have adopted a lot of methods to decrease the melting point of mixed nitrates, such as introducing additives $\left(\mathrm{Ca}\left(\mathrm{NO}_{3}\right)_{2} \cdot 4 \mathrm{H}_{2} \mathrm{O}\right.$ or $\left.\mathrm{LiNO}_{3}\right)$ and changing the proportion of solar salt $\left(60 \% \mathrm{NaNO}_{3} / 40 \% \mathrm{KNO}_{3}\right)$ and HITEC salt $\left(53 \% \mathrm{KNO}_{3} / 40 \% \mathrm{NaNO}_{2} / 7 \% \mathrm{NaNO}_{3}\right)$. And some researchers also make full use of the low-melting point materials as the PCMs, such as salt hydrates.

In order to obtain the nitrate salts with excellent thermal characteristics and substantial cost, there are a lot of options for low-temperature applications. Wu et al. [41] researched a new kind of binary molten salts $\mathrm{KNO}_{3} / \mathrm{Ca}\left(\mathrm{NO}_{3}\right)_{2} \cdot 4 \mathrm{H}_{2} \mathrm{O}$. The mixture had a regular melting peak and reached the eutectic point when the mass ratio of $\mathrm{KNO}_{3}$ and $\mathrm{Ca}$ $\left(\mathrm{NO}_{3}\right)_{2} \cdot 4 \mathrm{H}_{2} \mathrm{O}$ was $0.57: 0.43$, and its melting point was lowest. From the DSC curve, the melting point was $116.9^{\circ} \mathrm{C}$, which was lower than solar salt and HITEC salt, and the latent heat of this PCM was $78.79 \mathrm{~J} / \mathrm{g}$. Jiang et al. [42], $\mathrm{Wu}$ et al. [43], and Ren et al. [44] selected the quaternary molten salts $\mathrm{LiNO}_{3} / \mathrm{KNO}_{3} / \mathrm{NaNO}_{3} / \mathrm{Ca}\left(\mathrm{NO}_{3}\right)_{2}$ as the PCMs to study their thermal properties by DSC. The results showed that the composite of $27 \% \mathrm{LiNO}_{3} / 47 \% \mathrm{KNO}_{3} / 16 \% \mathrm{NaNO}_{3} / 10 \% \mathrm{Ca}$ $\left(\mathrm{NO}_{3}\right)_{2}$ as the PCM and calcium silicate as structural supporting material had a low-melting point $\left(103.5^{\circ} \mathrm{C}\right)$ and remained stable until $585.5^{\circ} \mathrm{C}$. The melting point of molten 
salts $20 \% \mathrm{LiNO}_{3} 6 \% \mathrm{KNO}_{3} / 10 \% \mathrm{NaNO}_{3} / 20 \% \mathrm{Ca}\left(\mathrm{NO}_{3}\right)_{2} \cdot 4 \mathrm{H}_{2} \mathrm{O}$ was $90^{\circ} \mathrm{C}$. And the melting point of sample No. 4 in 16 kinds of different mixing ratios of this PCM was up to $126.4^{\circ} \mathrm{C}$ and the latent heat of sample Nos. 14 and 15 was relatively large, larger than $100 \mathrm{~J} / \mathrm{g}$. Chen and Zhao [45] studied the cheap ternary molten salts $44 \% \mathrm{KNO}_{3} / 24 \% \mathrm{NaNO}_{3} / 32 \% \mathrm{Ca}$ $\left(\mathrm{NO}_{3}\right)_{2}$. The DSC results indicated that the mixture had the best thermal performance for latent heat storage with its melting point of $80^{\circ} \mathrm{C}$, latent heat of about $67 \mathrm{~J} / \mathrm{g}$, and the maximum stable temperature was $600^{\circ} \mathrm{C}$. Zhao and $\mathrm{Wu}$ [46] investigated the melting point of molten salt $\mathrm{LiNO}_{3} / \mathrm{KNO}_{3} / \mathrm{Ca}\left(\mathrm{NO}_{3}\right)_{2} \cdot \mathrm{H}_{2} \mathrm{O}$. Roget et al. [47] and Wang et al. [48] investigated the thermal properties of eutectic mixture $\mathrm{LiNO}_{3} / \mathrm{KNO}_{3} / \mathrm{NaNO}_{3}$ via DSC. The results showed that the melting point of $30 \% \mathrm{LiNO}_{3} / 18 \% \mathrm{NaNO}_{3} / 52 \%$ $\mathrm{KNO}_{3}$ is about $123^{\circ} \mathrm{C}$. And the DSC plot presented that the ternary salts $\left(25.9 \% \quad \mathrm{LiNO}_{3} / 20.06 \% \quad \mathrm{NaNO}_{3} / 54.1 \%\right.$ $\mathrm{KNO}_{3}$ ) start to melt at $118.87^{\circ} \mathrm{C}$, and the latent heat of this PCM was $68.96 \mathrm{~J} / \mathrm{g}$. Mantha et al. [49] studied the melting point and latent heat of quaternary system $\mathrm{LiNO}_{3} / \mathrm{NaNO}_{3} / \mathrm{KNO}_{3} / \mathrm{NaNO}_{2}$. And the DSC plot showed that the melting point of $99.02^{\circ} \mathrm{C}$ and the latent heat of the quaternary eutectic composition was $174.71 \mathrm{~J} / \mathrm{g}$.

In addition, salt hydrates are also an appropriate material for the low-temperature TES system. Liu and Yang [50] focused on the thermal properties of a novel $40 \%$ $\mathrm{Na}_{2} \mathrm{CO}_{3} \cdot 10 \mathrm{H}_{2} \mathrm{O} / 60 \% \mathrm{Na}_{2} \mathrm{HPO}_{4} \cdot 12 \mathrm{H}_{2} \mathrm{O}$ eutectic hydrate salt (EHS) PCM, which has been characterized by the DSC technique. The results showed that this salt was a suitable PCM as low-temperature heat storage in terms of the melting point of $27.3^{\circ} \mathrm{C}$ and latent heat of $220.2 \mathrm{~J} / \mathrm{g}$. Schmit et al. [51-53] investigated the influence of the composition $\mathrm{CaBr}_{2} \cdot 6 \mathrm{H}_{2} \mathrm{O}$ and $\mathrm{CaCl}_{2} \cdot 6 \mathrm{H}_{2} \mathrm{O}$ on the maximum storage capacity. For $\mathrm{CaBr}_{2} \cdot 6 \mathrm{H}_{2} \mathrm{O}$ and $\mathrm{CaCl}_{2} \cdot 6 \mathrm{H}_{2} \mathrm{O}$, the latent heat and the storage capacity of about $142 \mathrm{~J} / \mathrm{g}, 168 \mathrm{~J} / \mathrm{g}$ and $168 \mathrm{~J} / \mathrm{g}$, $221 \mathrm{~J} / \mathrm{g}$ were determined, respectively. Meanwhile, they researched the performance of hydrates $\mathrm{CaCl}_{2} \cdot 6 \mathrm{H}_{2} \mathrm{O}$ and $\mathrm{CaCl}_{2} \cdot 4 \mathrm{H}_{2} \mathrm{O}$. Ushak [54] studied the thermal properties of three inorganic salt $\mathrm{PCMs}(\mathrm{NaCl}, \mathrm{KCl}$, and $\mathrm{LiCl})$ by adding $\mathrm{CaCl}_{2} \cdot 4 \mathrm{H}_{2} \mathrm{O}$. For $\mathrm{CaCl}_{2} \cdot 4 \mathrm{H}_{2} \mathrm{O}$, the melting point and heat of fusion were $44.2^{\circ} \mathrm{C}$ and $99.6 \mathrm{~J} / \mathrm{g}$, respectively. And the addition reduced the melting point of alkaline salts; on the contrary, the heat of fusion of composite had slightly increased compared with the ones without additives. Wu and Wang [55] studied the shape-stabilized PCMs, the mixture of $50 \% \mathrm{Na}_{2} \mathrm{SO}_{4} \cdot 10 \mathrm{H}_{2} \mathrm{O} / 50 \% \mathrm{Na}_{2} \mathrm{HPO}_{4} \cdot 12 \mathrm{H}_{2} \mathrm{O}$ as $\mathrm{PCM}$, and $\mathrm{EG}$ as the supporting material. According to the DSC curves, the latent heat of the composite material can reach $172.3 \mathrm{~J} / \mathrm{g}$ with a melting temperature of $32.05^{\circ} \mathrm{C}$. Schmit et al. [56] proposed the three-step method to test the eutectic composition of $75 \% \mathrm{Zn}\left(\mathrm{NO}_{3}\right)_{2} \cdot 6 \mathrm{H}_{2} \mathrm{O} / 25 \% \mathrm{NH}_{4} \mathrm{NO}_{3}$ and $73 \%$ $\mathrm{Mn}\left(\mathrm{NO}_{3}\right)_{2} \cdot 6 \mathrm{H}_{2} \mathrm{O} / 27 \% \mathrm{NH}_{4} \mathrm{NO}_{3}$. And the latent heat of two composites was $135 \mathrm{~J} / \mathrm{g}$ and $133 \mathrm{~J} / \mathrm{g}$ with the melting points of $12.4^{\circ} \mathrm{C}$ and $3.9^{\circ} \mathrm{C}$, respectively. Huang et al. [57] prepared PMMA/ $/ \mathrm{Na}_{2} \mathrm{HPO}_{4} \cdot 7 \mathrm{H}_{2} \mathrm{O}$ by means of the suspension copolymerization solvent volatile method. According to the DSC curves, the melting point and latent heat were about $51^{\circ} \mathrm{C}$ and $150 \mathrm{~J} / \mathrm{g}$, respectively. Wu and Wang [58] and Liu and Yang [59] selected EHS $\mathrm{Na}_{2} \mathrm{SO}_{4} \cdot 10 \mathrm{H}_{2} \mathrm{O} / \mathrm{Na}_{2} \mathrm{HPO}_{4} \cdot 12 \mathrm{H}_{2} \mathrm{O}$ to study, and the melting point and latent heat of this EHS were $31.2^{\circ} \mathrm{C}$ and $280.1 \mathrm{~J} / \mathrm{g}$. The latent heat was higher than that of most of lowtemperature phase change materials showing a prominent heat storage capacity. Then $\mathrm{Na}_{2} \mathrm{HPO}_{4} \cdot 12 \mathrm{H}_{2} \mathrm{O} / \mathrm{Na}_{2} \mathrm{SO}_{4} \cdot 10 \mathrm{H}_{2} \mathrm{O}-\mathrm{SiO}_{2}$ as a novel shape-stabilized PCM was prepared, which selected $\mathrm{SiO}_{2}$ as the supporting material via sol-gel process. The DSC plots showed that the latent heat of the composite was $106.2 \mathrm{~J} / \mathrm{g}$ with its melting temperature of $30.13^{\circ} \mathrm{C}$, which were suitable for lowtemperature TES applications.

In the above literatures, the main works focus on the investigation of melting point and latent heat of lowtemperature inorganic PCMs, which indicated the salt hydrates are the most excellent materials as the lowtemperature PCM for low-temperature TES applications. And Tables 1 and 2 show the summary of the melting point and latent heat of mentioned low-temperature inorganic eutectic composites.

3.1.2. Medium-Temperature PCMs. In the applications of solar energy and industrial waste heat thermal energy storage system, PCMs with a melting temperature between $120^{\circ} \mathrm{C}$ and $300^{\circ} \mathrm{C}$ were also of great advantage. For example, a large amount of heat energy was required to generate process steam in this temperature range for applications in production of paper, food processing, textile industry, and so on. And a lot of investigations on the thermal performance of molten salts in the temperature range have been carried out by many researchers [60].

Based on the solar salts $\left(40 \% \mathrm{KNO}_{3} / 60 \% \mathrm{NaNO}_{3}\right)$, a large number of investigates were studied by DSC. Xiao et al. [61] investigated the $\mathrm{KNO}_{3} / \mathrm{NaNO}_{3}$-EG composite PCM, which the EG as the additive. According to the DSC curves, the peak temperature $\left(223.2^{\circ} \mathrm{C}\right)$ of composite was similar to that of $\mathrm{NaNO}_{3} / \mathrm{KNO}_{3}$, and the latent heat of composite was $128 \mathrm{~J} / \mathrm{g}$, while that of nitrates was $142.2 \mathrm{~J} / \mathrm{g}$. And Li et al. [62] also selected nitrate mixture $\mathrm{KNO}_{3} / \mathrm{NaNO}_{3}$ (50:50 mol.\%) as the PCM and SiC ceramic honeycomb $(\mathrm{SCH})$ as the heat transfer promoter to make a new composite $\mathrm{KNO}_{3} / \mathrm{NaNO}_{3}$-SiC. Compared with that of the pure PCM, the melting point of this composite shifted slightly, and its latent heat was $72.8 \mathrm{~J} / \mathrm{g}$ while the pure PCM was $106.3 \mathrm{~J} / \mathrm{g}$. Luo et al. [63] and Myers et al. [64] researched the thermal properties of pure binary salt $\mathrm{KNO}_{3} / \mathrm{NaNO}_{3}$, and the mixtures of $\mathrm{KNO}_{3} / \mathrm{NaNO}_{3}-\mathrm{CuO}$ by DSC. It was found that the melting point of these mixtures is about $222^{\circ} \mathrm{C}$, which closely agreed with that of the pure salts $\mathrm{KNO}_{3}$ /$\mathrm{NaNO}_{3}$, and the latent heat of these mixtures was approximately the same as that of the pure salts. $\mathrm{Xu}$ et al. [65] made use of diatomite to form stabilized $\mathrm{NaNO}_{3}$, which found that the diatomite and $\mathrm{NaNO}_{3}$ have an excellent chemical compatibility and were suitable for formulating composite PCM. And DSC measurements showed that the melting point of the PCM was approximately $307.8^{\circ} \mathrm{C}$ with a latent heat of $115.79 \mathrm{~J} / \mathrm{g}$.

There are some researches on the thermal properties with nitrates including $\mathrm{LiNO}_{3}, \mathrm{Ca}\left(\mathrm{NO}_{3}\right)_{2}$, and $\mathrm{CsNO}_{3}$. Zhou and Eames [60] studied the two binary salts (46\% $\begin{array}{lllllll}\mathrm{NaNO}_{3} / 54 \% & \mathrm{LiNO}_{3} \text { and } 40 \% & \mathrm{NaNO}_{3} / 60 \% & \mathrm{LiNO}_{3} \text { ) to }\end{array}$ 
TABLE 1: The melting point of low-temperature inorganic eutectic composites.

\begin{tabular}{|c|c|c|}
\hline Temperature $\left({ }^{\circ} \mathrm{C}\right)$ & Compound & References \\
\hline $0-40$ & $\begin{array}{c}\mathrm{Na}_{2} \mathrm{CO}_{3} \cdot 10 \mathrm{H}_{2} \mathrm{O} / \mathrm{Na}_{2} \mathrm{HPO}_{4} \cdot 12 \mathrm{H}_{2} \mathrm{O} \\
\quad \mathrm{CaCl}_{2} \cdot 4 \mathrm{H}_{2} \mathrm{O} / \mathrm{NaCl} \\
\mathrm{Na}_{2} \mathrm{SO}_{4} \cdot 10 \mathrm{H}_{2} \mathrm{O} / \mathrm{Na}_{2} \mathrm{HPO}_{4} \cdot 12 \mathrm{H}_{2} \mathrm{O}\end{array}$ & $\begin{array}{c}{[50]} \\
{[54]} \\
{[55,58,59]} \\
\end{array}$ \\
\hline $40-80$ & $\begin{array}{c}\mathrm{Ca}\left(\mathrm{NO}_{3}\right)_{2} / \mathrm{NaNO}_{3} / \mathrm{KNO}_{3} \\
\mathrm{KNO}_{3} / \mathrm{Ca}\left(\mathrm{NO}_{3}\right)_{2} / \mathrm{LiNO}_{3} \\
\mathrm{CaCl}_{2} \cdot 4 \mathrm{H}_{2} \mathrm{O} / \mathrm{KCl} \\
\end{array}$ & $\begin{array}{l}{[45]} \\
{[46]} \\
{[54]}\end{array}$ \\
\hline $80-120$ & $\begin{array}{c}\mathrm{KNO}_{3} / \mathrm{Ca}\left(\mathrm{NO}_{3}\right)_{2} \\
\mathrm{LiNO}_{3} / \mathrm{NaNO}_{3} / \mathrm{KNO}_{3} / \mathrm{Ca}\left(\mathrm{NO}_{3}\right)_{2} \\
\mathrm{Ca}\left(\mathrm{NO}_{3}\right)_{2} / \mathrm{KNO}_{3} / \mathrm{NaNO}_{3} / \mathrm{LiNO}_{3} / \mathrm{K}_{2} \mathrm{CO}_{3} \\
\mathrm{Ca}\left(\mathrm{NO}_{3}\right)_{2} \cdot 4 \mathrm{H}_{2} \mathrm{O} / \mathrm{KNO}_{3} / \mathrm{NaNO}_{3} / \mathrm{LiNO}_{3} / \mathrm{Na}_{2} \mathrm{CO}_{3} \\
\mathrm{Ca}\left(\mathrm{NO}_{3}\right)_{2} / \mathrm{KNO}_{3} / \mathrm{NaNO}_{2} / \mathrm{NaNO}_{3} \\
\mathrm{LiNO}_{3} / \mathrm{NaNO}_{3} / \mathrm{KNO}_{3} \\
\mathrm{LiNO}_{3} / \mathrm{NaNO}_{3} / \mathrm{KNO}_{3} / \mathrm{NaNO}_{2}\end{array}$ & $\begin{array}{c}{[41]} \\
{[42-44]} \\
{[43]} \\
{[43]} \\
{[43]} \\
{[47,48]} \\
{[49]} \\
\end{array}$ \\
\hline
\end{tabular}

TABLE 2: The latent heat of low-temperature inorganic eutectic composites.

\begin{tabular}{|c|c|c|}
\hline $\begin{array}{l}\text { Latent heat } \\
(\mathrm{J} / \mathrm{g})\end{array}$ & Compound & References \\
\hline \multirow{4}{*}{$0-100$} & $\mathrm{KNO}_{3} / \mathrm{Ca}\left(\mathrm{NO}_{3}\right)_{2} \cdot 4 \mathrm{H}_{2} \mathrm{O}$ & {$[41]$} \\
\hline & $\mathrm{Ca}\left(\mathrm{NO}_{3}\right)_{3} / \mathrm{NaNO}_{3} / \mathrm{KNO}_{3}$ & {$[45]$} \\
\hline & $\mathrm{LiNO}_{3} / \mathrm{NaNO}_{3} / \mathrm{KNO}_{3}$ & {$[48]$} \\
\hline & $\mathrm{CaCl}_{2} \cdot 4 \mathrm{H}_{2} \mathrm{O} / \mathrm{NaCl}$ & {$[54]$} \\
\hline \multirow{7}{*}{$100-200$} & $\mathrm{LiNO}_{3} / \mathrm{NaNO}_{3} / \mathrm{KNO}_{3} / \mathrm{Ca}\left(\mathrm{NO}_{3}\right)_{2}$ & {$[42]$} \\
\hline & $\mathrm{KNO}_{3} / \mathrm{Ca}\left(\mathrm{NO}_{3}\right)_{2} / \mathrm{LiNO}_{3}$ & {$[46]$} \\
\hline & $\mathrm{KNO}_{3} / \mathrm{NaNO}_{3} / \mathrm{LiNO}_{3} / \mathrm{Ca}$ & [44] \\
\hline & $\begin{array}{c}\left(\mathrm{NO}_{3}\right)_{2} \cdot 4 \mathrm{H}_{2} \mathrm{O} \\
\mathrm{LiNO}_{3} / \mathrm{KNO}_{3} / \mathrm{NaNO}_{3}\end{array}$ & {$[47]$} \\
\hline & $\mathrm{LiNO}_{3} / \mathrm{NaNO}_{3} / \mathrm{KNO}_{3} / \mathrm{NaNO}_{2}$ & [49] \\
\hline & $\mathrm{CaCl}_{2} \cdot 4 \mathrm{H}_{2} \mathrm{O} / \mathrm{LiCl}$ & {$[54]$} \\
\hline & $\mathrm{Zn}\left(\mathrm{NO}_{3}\right)_{2} \cdot 6 \mathrm{H}_{2} \mathrm{O} / \mathrm{NH}_{4} \mathrm{NO}_{3}$ & {$[56]$} \\
\hline \multirow{2}{*}{$200-300$} & $\mathrm{Na}_{2} \mathrm{CO}_{3} \cdot 10 \mathrm{H}_{2} \mathrm{O} / \mathrm{Na}_{2} \mathrm{HPO}_{4} \cdot 12 \mathrm{H}_{2} \mathrm{O}$ & {$[50]$} \\
\hline & $\mathrm{Na}_{2} \mathrm{SO}_{4} \cdot 10 \mathrm{H}_{2} \mathrm{O} / \mathrm{Na}_{2} \mathrm{HPO}_{4} \cdot 12 \mathrm{H}_{2} \mathrm{O}$ & {$[55,58,59]$} \\
\hline
\end{tabular}

estimate their suitability for the medium-temperature TES system. The average melting points of the binary systems were $193.87^{\circ} \mathrm{C}$ and $193.27^{\circ} \mathrm{C}$, respectively. The average latent heat of the samples was $261.7 \mathrm{~J} / \mathrm{g}$ and $244.1 \mathrm{~J} / \mathrm{g}$, respectively. Fernández et al. $[66,67]$ found that the melting point and latent heat of the $\mathrm{LiNO}_{3} / \mathrm{KNO}_{3} / \mathrm{NaNO}_{3} / \mathrm{Ca}\left(\mathrm{NO}_{3}\right)_{2}$ is $130.61^{\circ} \mathrm{C}$ and $157.5 \mathrm{~J} / \mathrm{g}$, respectively, and the melting point of $\mathrm{KNO} 3 / \mathrm{NaNO}_{3} / \mathrm{Ca}\left(\mathrm{NO}_{3}\right)_{2} \cdot 4 \mathrm{H}_{2} \mathrm{O}$ is $132.08^{\circ} \mathrm{C}$, which was significantly lower than the binary salt $\mathrm{KNO}_{3} / \mathrm{NaNO}_{3}$ with the melting point of $223^{\circ} \mathrm{C}$. Mohammad et al. [68] studied the thermal properties of the composition $29.63 \%$ $\begin{array}{lllll}\mathrm{LiNO}_{3} / 57.14 \% & \mathrm{KNO}_{3} / 13.23 \% & \mathrm{NaNO}_{3} & \text { obtained by the }\end{array}$ thermodynamic analysis. The melting point of $122.8^{\circ} \mathrm{C}$ obtained from DSC was excellently in agreement with the predicted melting point of $120.84^{\circ} \mathrm{C}$ (from FactSage) and the latent heat was $126.9 \mathrm{~J} / \mathrm{g}$. Pramod et al. [69] prepared the mixtures of $\mathrm{LiNO}_{3}, \mathrm{KNO}_{3}$, and $\mathrm{Ca}\left(\mathrm{NO}_{3}\right)_{2}$ as the ternary molten salts with the melting points of $137^{\circ} \mathrm{C}$. And $\mathrm{Li}$ et al. [70] chose a lower percentage of $\mathrm{CsNO}_{3}$ to add into the ternary nitrate salts in order to obtain three kinds of quandary salts $\left(\mathrm{LiNO}_{3} / \mathrm{KNO}_{3} / \mathrm{Ca}\left(\mathrm{NO}_{3}\right)_{2} / \mathrm{CsNO}_{3}\right)$. And the DSC plot results indicated that the phase transitions of the samples occurred at $113.0-113.1^{\circ} \mathrm{C}$. The fusion heat of them was $95.61 \mathrm{~J} / \mathrm{g}, 86.70 \mathrm{~J} / \mathrm{g}$, and $87.95 \mathrm{~J} / \mathrm{g}$, respectively.

And some studies utilize chloride to satisfy the demand of medium-temperature TES system. Huang et al. [71, 72] selected the system with $50 \% \mathrm{LiNO}_{3} / 50 \% \mathrm{KCl}$ as the PCM and expanded graphite as the heat transfer promoter to prepare the composite of $\mathrm{LiNO}_{3} / \mathrm{KCl}-\mathrm{EG}$. The experimental results revealed that the melting temperature of this composite was $165.60^{\circ} \mathrm{C}$, and the latent heat ranging from $142.41 \mathrm{~J} / \mathrm{g}$ to $178.10 \mathrm{~J} / \mathrm{g}$ was dependent on the mass fraction of EG. Zhong et al. [73] selected three kinds of composites $\left(\mathrm{LiNO}_{3} / \mathrm{KCl}-\mathrm{EG}, \mathrm{LiNO}_{3} / \mathrm{NaNO}_{3}-\mathrm{EG}\right.$, and $\left.\mathrm{LiNO}_{3} / \mathrm{NaCl}-\mathrm{EG}\right)$ as the PCM. The DSC plots indicated that the melting temperatures of them were $171.0^{\circ} \mathrm{C}, 199.3^{\circ} \mathrm{C}$, and $229.7^{\circ} \mathrm{C}$, respectively, and the latent heat was $193.5 \mathrm{~J} / \mathrm{g}, 232.7 \mathrm{~J} / \mathrm{g}$, and $305.3 \mathrm{~J} / \mathrm{g}$, respectively. Zhou and Eames [74] investigated the eutectic salt of $87 \% \mathrm{LiNO}_{3} / 13 \% \mathrm{NaCl}$ to evaluate its potential for latent heat storage with medium-temperature applications $\left(<300^{\circ} \mathrm{C}\right)$. From the DSC curves, the average phase change temperature measured was $220^{\circ} \mathrm{C}$. And the measured average latent heat value was about $310 \mathrm{~J} / \mathrm{g}$. Peng et al. [75-77] investigated that the eutectic properties of the $\mathrm{NaCl} / \mathrm{NaF} / \mathrm{NaNO}_{3}$. It was found that there was a sharp endothermic peak around $293.5^{\circ} \mathrm{C}$ and absorbing heat quantity of $155.5 \mathrm{~J} / \mathrm{g}$ in the DSC curve, which represented the melting point and latent heat. And the molten salts $\mathrm{KNO}_{3} / \mathrm{NaNO}_{3} / \mathrm{NaNO}_{2}$ with $5 \%$ additive A were prepared by the statical mixing method. Compared with ternary nitrate salt, the melting point and latent heat of the composite were decreased from $138.79^{\circ} \mathrm{C}$ to $137.62^{\circ} \mathrm{C}$ and from $59.14 \mathrm{~J} / \mathrm{g}$ to $56.57 \mathrm{~J} / \mathrm{g}$, respectively. And the DSC curve showed that the melting point of $\mathrm{KCl} / \mathrm{NaNO}_{3} / \mathrm{NaCl} / \mathrm{NaNO}_{3}$ was $140^{\circ} \mathrm{C}$.

In the above literatures, the main works focus on the investigation of melting point and latent heat of mediumtemperature inorganic phase change materials (PCMs). It is found that a majority of nitrates and a small amount of chlorides can achieve the demand of medium-temperature thermal energy storage applications. Meanwhile, the summary of the melting point and latent heat of mentioned medium-temperature inorganic eutectic composites is displayed in Tables 3 and 4, respectively. 
TABLE 3: The melting point of medium-temperature inorganic eutectic composites.

\begin{tabular}{|c|c|c|}
\hline Temperature $\left({ }^{\circ} \mathrm{C}\right)$ & Compound & References \\
\hline \multirow{7}{*}{$120-180$} & $\mathrm{LiNO}_{3} / \mathrm{Ca}\left(\mathrm{NO}_{3}\right)_{2} / \mathrm{NaNO}_{3} / \mathrm{KNO}_{3}$ & [66] \\
\hline & $\mathrm{Ca}\left(\mathrm{NO}_{3}\right)_{2} \cdot 4 \mathrm{H}_{2} \mathrm{O} / \mathrm{NaNO}_{3} / \mathrm{KNO}_{3}$ & [67] \\
\hline & $\mathrm{LiNO}_{3} / \mathrm{KNO}_{3} / \mathrm{NaNO}_{3}$ & {$[67,68]$} \\
\hline & $\mathrm{Ca}\left(\mathrm{NO}_{3}\right)_{2} \cdot 4 \mathrm{H}_{2} \mathrm{O} / \mathrm{LiNO}_{3} / \mathrm{KNO}_{3}$ & {$[67,69]$} \\
\hline & $\mathrm{LiNO}_{3} / \mathrm{KCl}$ & {$[71,73]$} \\
\hline & $\mathrm{KNO}_{3} / \mathrm{NaNO}_{2} / \mathrm{NaNO}_{3}$ & {$[76]$} \\
\hline & $\mathrm{KCl} / \mathrm{NaNO}_{2} / \mathrm{NaCl} / \mathrm{NaNO}_{3}$ & [77] \\
\hline \multirow{3}{*}{$180-240$} & $\mathrm{NaNO}_{3} / \mathrm{LiNO}_{3}$ & {$[60,73]$} \\
\hline & $\mathrm{NaNO}_{3} / \mathrm{KNO}_{3}$ & {$[61-64]$} \\
\hline & $\mathrm{LiNO}_{3} / \mathrm{NaCl}$ & {$[73,74]$} \\
\hline \multirow{2}{*}{$240-300$} & $\mathrm{NaNO}_{3}$ & {$[64,65]$} \\
\hline & $\mathrm{KNO}_{3}$ & {$[64]$} \\
\hline
\end{tabular}

TABLE 4: The latent heat of medium-temperature inorganic eutectic composites.

\begin{tabular}{lcc}
\hline Latent heat $(\mathrm{J} / \mathrm{g})$ & Compound & References \\
\hline & $\mathrm{LiNO}_{3} / \mathrm{Ca}\left(\mathrm{NO}_{3}\right)_{2} / \mathrm{NaNO}_{3} / \mathrm{KNO}_{3}$ & {$[66]$} \\
$0-100$ & $\mathrm{LiNO}_{3} / \mathrm{KNO}_{3} / \mathrm{Ca}\left(\mathrm{NO}_{3}\right)_{2} \cdot 4 \mathrm{H}_{2} \mathrm{O}$ & {$[67]$} \\
& $\mathrm{KNO}_{3} / \mathrm{NaNO}_{2} / \mathrm{NaNO}_{3}$ & {$[76]$} \\
& $\mathrm{KNO}_{3}$ & {$[64]$} \\
\hline \multirow{4}{*}{$100-200$} & $\mathrm{Ca}\left(\mathrm{NO}_{3}\right)_{2} \cdot 4 \mathrm{H}_{2} \mathrm{O} / \mathrm{NaNO}_{3} / \mathrm{KNO}_{3}$ & {$[67]$} \\
& $\mathrm{LiNO}_{3} / \mathrm{KNO}_{3} / \mathrm{NaNO}_{3}$ & {$[67,68]$} \\
& $\mathrm{NaNO}_{3} / \mathrm{KNO}_{3}$ & {$[61-63,74]$} \\
& $\mathrm{LiNO}_{3} / \mathrm{KCl}$ & {$[73]$} \\
\hline \multirow{2}{*}{$200-300$} & $\mathrm{NaNO}_{3} / \mathrm{LiNO}$ & {$[60,73]$} \\
& $\mathrm{LiNO}_{3} / \mathrm{KCl}_{3}$ & {$[71]$} \\
\hline $300-400$ & $\mathrm{LiNO}_{3} / \mathrm{NaCl}$ & {$[73,74]$} \\
\hline
\end{tabular}

3.1.3. High-Temperature PCMs. Recently, molten salts were considered as the ideal media for high-temperature $\left(>300^{\circ} \mathrm{C}\right)$ thermal energy storage and transfer with the desirable characteristics including the broad operating temperature, high latent heat, high thermal capacity, good thermal/chemical stability, lower viscosity and vapor pressure, and lower cost. And some commercial salts have been presented and applied in concentrating solar power (CSP) plants [78]. Especially, inorganic salts were promising candidates for hightemperature PCMs because they produce a large latent heat without substantial density change during the process of solidliquid phase transformation [79].

In this section, we will summarize and analyze the present investigations of high-temperature inorganic PCMs in terms of thermal properties, such as melting point and latent heat, via DSC. Generally, the high-temperature inorganic PCMs can be divided into carbonates, metal halogenide, the mixtures of them, alloy, and so on.

There are some studies on thermal properties including carbonates and their composite salts. Liu et al. [79] studied the thermal properties of six kinds of mixtures including $32 \% \mathrm{Li}_{2} \mathrm{CO}_{3} / 35 \% \quad \mathrm{~K}_{2} \mathrm{CO}_{3} / 33 \% \quad \mathrm{Na}_{2} \mathrm{CO}_{3}, 28.5 \% \quad \mathrm{Li}_{2} \mathrm{CO}_{3} / 71.5 \%$ $\mathrm{K}_{2} \mathrm{CO}_{3}, 35 \% \mathrm{Li}_{2} \mathrm{CO}_{3} / 65 \% \mathrm{~K}_{2} \mathrm{CO}_{3}, 22 \% \mathrm{Li}_{2} \mathrm{CO}_{3} / 62 \% \mathrm{~K}_{2} \mathrm{CO}_{3} / 16 \%$ $\mathrm{Na}_{2} \mathrm{CO}_{3}, 52 \% \mathrm{MgCl}_{2} / 48 \% \mathrm{NaCl}$, and $64 \% \mathrm{MgCl}_{2} / 36 \% \mathrm{KCl}$, and the melting point and latent heat measured in this study were found to be $396.7^{\circ} \mathrm{C}, 479.9^{\circ} \mathrm{C}, 503.7^{\circ} \mathrm{C}, 425.5^{\circ} \mathrm{C}, 439.1^{\circ} \mathrm{C}$, and $459.1^{\circ} \mathrm{C}$ and $278.9 \mathrm{~J} / \mathrm{g}, 234.3 \mathrm{~J} / \mathrm{g}, 295.2 \mathrm{~J} / \mathrm{g}, 274.7 \mathrm{~J} / \mathrm{g}, 204.2 \mathrm{~J} / \mathrm{g}$, and $210.2 \mathrm{~J} / \mathrm{g}$, respectively. Sang et al. [80] selected $40 \%$ $\mathrm{Li}_{2} \mathrm{CO}_{3} / 40 \% \mathrm{~K}_{2} \mathrm{CO}_{3} / 20 \% \mathrm{Na}_{2} \mathrm{CO}_{3}$ ternary carbonates as the PCM. And the DSC results showed the melting point of $410.5^{\circ} \mathrm{C}$. And the ternary carbonates mixed with $10 \% \mathrm{LiOH}$, $10 \% \mathrm{KOH}$, and $10 \% \mathrm{Ca}(\mathrm{OH})_{2}$ have the melting points of $331^{\circ} \mathrm{C}, 326^{\circ} \mathrm{C}$, and $390^{\circ} \mathrm{C}$, respectively. Wu et al. [81] researched 36 kinds of mixed carbonate molten salts which were prepared by mixing $\mathrm{Li}_{2} \mathrm{CO}_{3}, \mathrm{~K}_{2} \mathrm{CO}_{3}$, and $\mathrm{Na}_{2} \mathrm{CO}_{3}$. From the DSC curves, it indicated that the melting points of major ternary carbonate were close at around $400^{\circ} \mathrm{C}$ and the decomposition temperatures of them were between 800 and $850^{\circ} \mathrm{C}$. Jiang et al. [82] investigated a potential eutectic salt $\left(\mathrm{Na}_{2} \mathrm{CO}_{3} / \mathrm{Li}_{2} \mathrm{CO}_{3}\right)$ as the high-temperature PCM. The DSC curve shows that the eutectic salt has a melting point of $498.3^{\circ} \mathrm{C}$, with the latent heat of $330.8 \mathrm{~J} / \mathrm{g}$. Omran et al. [83] investigated the influence of the moisture on the latent heat of a binary mixture $\left(\mathrm{Li}_{2} \mathrm{CO}_{3} / \mathrm{K}_{2} \mathrm{CO}_{3}\right)$. The DSC result showed the onset temperature of $502.43^{\circ} \mathrm{C}$, the peak temperature of $502.42^{\circ} \mathrm{C}$, and the latent heat of $314.29 \mathrm{~J} / \mathrm{g}$. Tao et al. [84] proposed four kinds of carbon nanomaterials mixed into binary carbonate eutectic salts $\left(\mathrm{Li}_{2} \mathrm{CO}_{3} / \mathrm{K}_{2} \mathrm{CO}_{3}\right)$ as the composite PCM. According to the DSC curves, the pure PCM has the melting point and melting enthalpy of $486.40^{\circ} \mathrm{C}$ and $331.50 \mathrm{~J} / \mathrm{g}$, respectively. However, the melting point and melting enthalpy of composition decreased with the increase of nanomaterial. Zhang et al. [85] prepared the composites of $32.1 \%$ $\mathrm{Li}_{2} \mathrm{CO}_{3} / 33.4 \% \mathrm{Na}_{2} \mathrm{CO}_{3} / 34.5 \% \mathrm{~K}_{2} \mathrm{CO}_{3}$ with $\mathrm{T}-\mathrm{ZnOw}$ by the solution-evaporation method. There was a slight change with regard to latent heat and melting point of ternary carbonate/T$\mathrm{ZnOw}$, and the value ranged from 403 to $406^{\circ} \mathrm{C}$.

It is well known that the alkali halides are the materials with high-melting point (the temperature more than $600^{\circ} \mathrm{C}$ ), such as fluorides, chlorides, and their eutectic salts. In order to meet the needs of solar energy storage, Wei et al. [86] and $\mathrm{Du}$ et al. [87] et al. chose the ternary chloride salt $\mathrm{NaCl} /$ $\mathrm{CaCl}_{2} / \mathrm{MgCl}_{2}$ to study the thermal properties. And the lowest eutectic temperature was $424.05^{\circ} \mathrm{C}$ which was in good agreement with experimental results of $424^{\circ} \mathrm{C}$ measured by DSC. And the latent heat of the PCM is about $201.50 \mathrm{~J} / \mathrm{g}$, which was so large that this ternary eutectic chloride salt was suitable for the TES system. Tian et al. [78] chose binary eutectic chloride $\left(\mathrm{NaCl} / \mathrm{CaCl}_{2}\right)$ as the high-temperature $\left(>400^{\circ} \mathrm{C}\right)$ heat storage medium, and the EG was adopted to enhance the heat transfer performance of this system. From the DSC plot, the melting point and the phase change latent heat of binary eutectic chloride were $506.2^{\circ} \mathrm{C}$ and $164.2 \mathrm{~J} / \mathrm{g}$. Khokhlov et al. [88] studied the key thermal properties of some molten salt eutectics. The latent heat of mixture $(\mathrm{LiF} / \mathrm{NaF} / \mathrm{KF})$ measured was about $385 \mathrm{~J} / \mathrm{g}$ with the melting point of $731 \mathrm{~K}$, and there were two kinds of eutectics $\mathrm{LiF} / \mathrm{NaF} / \mathrm{ZrF}_{4}$ with the melting point and latent heat of $842.7 \mathrm{~K}, 727.9 \mathrm{~K}$ and $106.4 \mathrm{~J} / \mathrm{g}, 40.7 \mathrm{~J} / \mathrm{g}$, respectively.

And the melting points of the mixtures including carbonates, halogenated salts, and nitrates are relatively higher. The research on the melting point and latent heat of this mixture and other materials has been investigated by many researchers. Li et al. $[89,90]$ analyzed the thermophysical properties of pure $\mathrm{NaNO}_{3}$ with the melting point and latent 
TABLE 5: The melting point of high-temperature inorganic eutectic composites.

\begin{tabular}{|c|c|c|}
\hline $\begin{array}{l}\text { Temperature } \\
\left({ }^{\circ} \mathrm{C}\right)\end{array}$ & Compound & References \\
\hline $300-400$ & $\begin{array}{c}\mathrm{Li}_{2} \mathrm{CO}_{3} / \mathrm{K}_{2} \mathrm{CO}_{3} / \mathrm{Na}_{2} \mathrm{CO}_{3} \\
\mathrm{Li}_{2} \mathrm{CO}_{3} / \mathrm{Na}_{2} \mathrm{CO}_{3} / \mathrm{K}_{2} \mathrm{CO}_{3} / \mathrm{NaNO}_{3} \\
\mathrm{Li}_{2} \mathrm{CO}_{3} / \mathrm{Na}_{2} \mathrm{CO}_{3} / \mathrm{K}_{2} \mathrm{CO}_{3} / \mathrm{NaOH} \\
\mathrm{Mg} / \mathrm{Zn} / \mathrm{Al}\end{array}$ & $\begin{array}{c}{[79,81]} \\
{[91]} \\
{[91]} \\
{[96]}\end{array}$ \\
\hline $400-500$ & $\begin{array}{c}\mathrm{Li}_{2} \mathrm{CO}_{3} / \mathrm{K}_{2} \mathrm{CO}_{3} / \mathrm{NaCO}_{3} \\
\mathrm{Li}_{2} \mathrm{CO}_{3} / \mathrm{K}_{2} \mathrm{CO}_{3} \\
\mathrm{MgCl} / 2 / \mathrm{NaCl} \\
\mathrm{LiF} / \mathrm{NaF} / \mathrm{KF} \\
\mathrm{LiF} / \mathrm{NaF} / \mathrm{ZrF}_{4} \\
\mathrm{NaCl} / \mathrm{CaCl}_{2} / \mathrm{MgCl}_{2} \\
\mathrm{Na}_{2} \mathrm{CO}_{3} / \mathrm{Li}_{2} \mathrm{CO}_{3} \\
\mathrm{LiF} / \mathrm{Na}_{2} \mathrm{CO}_{3} / \mathrm{K}_{2} \mathrm{CO}_{3} \\
\end{array}$ & $\begin{array}{c}{[79-81,85,91]} \\
{[79,84]} \\
{[79]} \\
{[88]} \\
{[88]} \\
{[86,87]} \\
{[82]} \\
{[92]} \\
\end{array}$ \\
\hline $500-600$ & $\begin{array}{c}\mathrm{NaCl} / \mathrm{CaCl}_{2} \\
\mathrm{Li}_{2} \mathrm{CO}_{3} / \mathrm{K}_{2} \mathrm{CO}_{3} \\
\mathrm{LiF} / \mathrm{NaF} / \mathrm{ZrF}_{4} \\
\mathrm{Al} / \mathrm{Cu} \\
\mathrm{Al} / \mathrm{Si} \\
\mathrm{Al} / \mathrm{Cu} / \mathrm{Zn} \\
\end{array}$ & $\begin{array}{c}{[78]} \\
{[79,83]} \\
{[88]} \\
{[94]} \\
{[94]} \\
{[94]}\end{array}$ \\
\hline $600-700$ & $\begin{array}{c}\mathrm{Na}_{2} \mathrm{CO}_{3} / \mathrm{NaCl} \\
\mathrm{Al} / \mathrm{Mg} \\
\mathrm{Al} / \mathrm{Cu} / \mathrm{Zn} \\
\mathrm{Al} / \mathrm{Al}_{2} \mathrm{O}_{3}\end{array}$ & $\begin{array}{l}{[93]} \\
{[94]} \\
{[94]} \\
{[95]}\end{array}$ \\
\hline
\end{tabular}

heat of about $306^{\circ} \mathrm{C}$ and $178 \mathrm{~J} / \mathrm{g}$, respectively. Sang et al. [91] researched that the average melting point of the studied ternary carbonates, the nitrate-mixed molten salts, and the hydroxide-mixed molten salts were $402.1^{\circ} \mathrm{C}, 394.7^{\circ} \mathrm{C}$, and $323.2^{\circ} \mathrm{C} . \mathrm{NaOH}$ as the additive has more significant effect on lowering the melting point of ternary carbonate mixtures. Wang et al. [92] studied the melting point and latent heat of the novel eutectic composition in the $\mathrm{LiF} / \mathrm{Na}_{2} \mathrm{CO}_{3} / \mathrm{K}_{2} \mathrm{CO}_{3}$ ternary system via DSC. From the DSC curve, the average melting point was $420.9^{\circ} \mathrm{C}$ and the latent heat was $202.46 \mathrm{~J} / \mathrm{g}$. Jiang et al. [93] selected the eutectic molten salt $\left(\mathrm{Na}_{2} \mathrm{CO}_{3} / \mathrm{NaCl}\right)$ as a new high-temperature PCM for solar thermal energy storage. From the DSC plot, the melting point and latent heat of the eutectic composition were $637^{\circ} \mathrm{C}$ and $283.3 \mathrm{~J} / \mathrm{g}$, respectively.

In addition, the metal and alloy, as a high-temperature material and high thermal conductivity, have attracted much attention. Wei et al. [94] prepared ten aluminum alloy samples using a casting method by designing compositions of $\mathrm{Al} / \mathrm{Si}, \mathrm{Al} / \mathrm{Cu}, \mathrm{Al} / \mathrm{Mg}$, and $\mathrm{Al} / \mathrm{Cu} / \mathrm{Zn}$ alloys. Additions of $\mathrm{Cu}, \mathrm{Zn}$, and $\mathrm{Si}$ in the samples all helped in reducing the melting point of the aluminum alloys. The Al/19.7Si alloy sample had the highest latent heat of $372.1 \mathrm{~J} / \mathrm{g}$. Yolshina and Kvashinchev [95] investigated the synthesis of nanocomposites of $\mathrm{Al} / \mathrm{Al}_{2} \mathrm{O}_{3}$ with improved physical properties. The melting point of the nanocomposite $\left(668^{\circ} \mathrm{C}\right)$ was only more than $6^{\circ} \mathrm{C}$ compared with the initial aluminum $\left(662^{\circ} \mathrm{C}\right)$. The aim of this study was to investigate high thermal conductive materials such as metallic alloys for latent heat energy storage in CSP applications. Rwasueño and Faik [96] investigated two ternary eutectic alloys, $\mathrm{Mg}_{70} \mathrm{Zn}_{24.9} \mathrm{Al}_{5.1}$ and $\mathrm{Zn}_{85.8} \mathrm{Al}_{8.2} \mathrm{Mg}_{6}$. The DSC curves indicated that the melting
TABle 6: The latent heat of high-temperature inorganic eutectic composites.

\begin{tabular}{|c|c|c|}
\hline Latent heat $(\mathrm{J} / \mathrm{g})$ & Compound & References \\
\hline \multirow{2}{*}{$0-100$} & $\mathrm{~K}_{2} \mathrm{CO}_{3} / \mathrm{Li}_{2} \mathrm{CO}_{3} / \mathrm{Na}_{2} \mathrm{CO}_{3}$ & [81] \\
\hline & $\mathrm{LiF} / \mathrm{NaF} / \mathrm{ZrF}_{4}$ & [88] \\
\hline \multirow{3}{*}{$100-200$} & $\mathrm{NaCl} / \mathrm{CaCl}_{2}$ & {$[78]$} \\
\hline & $\mathrm{K}_{2} \mathrm{CO}_{3} / \mathrm{Li}_{2} \mathrm{CO}_{3} / \mathrm{Na}_{2} \mathrm{CO}_{3}$ & {$[81]$} \\
\hline & $\mathrm{LiF} / \mathrm{NaF} / \mathrm{ZrF}_{4}$ & {$[88]$} \\
\hline \multirow{9}{*}{$200-300$} & $\mathrm{Li}_{2} \mathrm{CO}_{3} / \mathrm{K}_{2} \mathrm{CO}_{3} / \mathrm{Na}_{2} \mathrm{CO}_{3}$ & {$[79,85]$} \\
\hline & $\mathrm{Li}_{2} \mathrm{CO}_{3} / \mathrm{K}_{2} \mathrm{CO}_{3}$ & [79] \\
\hline & $\mathrm{MgCl}_{2} / \mathrm{NaCl}$ & [79] \\
\hline & $\mathrm{NaCl} / \mathrm{CaCl}_{2} / \mathrm{MgCl}_{2}$ & [87] \\
\hline & $\mathrm{LiF} / \mathrm{Na}_{2} \mathrm{CO}_{3} / \mathrm{K}_{2} \mathrm{CO}_{3}$ & {$[92]$} \\
\hline & $\mathrm{Na}_{2} \mathrm{CO}_{3} / \mathrm{NaCl}$ & [93] \\
\hline & $\mathrm{Al} / \mathrm{Cu}$ & {$[94]$} \\
\hline & $\mathrm{Al} / \mathrm{Mg}$ & {$[94]$} \\
\hline & $\mathrm{Al} / \mathrm{Cu} / \mathrm{Zn}$ & {$[94]$} \\
\hline \multirow{6}{*}{$300-400$} & $\mathrm{LiF} / \mathrm{NaF} / \mathrm{KF}$ & {$[88]$} \\
\hline & $\mathrm{Na}_{2} \mathrm{CO}_{3} / \mathrm{Li}_{2} \mathrm{CO}_{3}$ & {$[82]$} \\
\hline & $\mathrm{Li}_{2} \mathrm{CO}_{3} / \mathrm{K}_{2} \mathrm{CO}_{3}$ & {$[83,84]$} \\
\hline & $\mathrm{Al} / \mathrm{Cu}$ & {$[94]$} \\
\hline & $\mathrm{Al} / \mathrm{Si}$ & {$[94]$} \\
\hline & $\mathrm{Al} / \mathrm{Cu} / \mathrm{Zn}$ & [94] \\
\hline
\end{tabular}

point and the latent heat of the two alloys were $339.5^{\circ} \mathrm{C}$ and $157 \mathrm{~J} / \mathrm{g}$ and $343.5^{\circ} \mathrm{C}$ and $104 \mathrm{~J} / \mathrm{g}$, respectively.

In the above literatures, the main works focus on the research of melting point and latent heat of high-temperature inorganic PCMs via DSC. It can be found that the carbonates $\left(\mathrm{Li}_{2} \mathrm{CO}_{3}, \mathrm{Na}_{2} \mathrm{CO}_{3}\right.$, and $\left.\mathrm{K}_{2} \mathrm{CO}_{3}\right)$, alkali halides $\left(\mathrm{NaCl}, \mathrm{CaCl}_{2}\right.$, $\mathrm{MgCl}_{2}, \mathrm{LiF}, \mathrm{NaF}$, and $\mathrm{KF}$ ), the mixtures of them (such as $\mathrm{Na}_{2} \mathrm{CO}_{3} / \mathrm{NaCl}$ ), metal, alloy (such as $\mathrm{Al} / \mathrm{Cu} / \mathrm{Zn}$ ), and so on have been the focus of high-temperature PCMs. Therefore, the summary of the melting point and latent heat of mentioned high-temperature inorganic eutectic composites was demonstrated in Tables 5 and 6.

According to the inorganic PCMs mentioned above, the rough relationship of phase change temperature and inorganic PCMs is displayed in Figure 1, where the melting point of the material increases gradually from the bottom to the top.

3.2. Organic Materials. According to the phase change temperature and heat storage capacities of PCMs, a wide variety of them are utilized in the different applications. A majority of materials including inorganic compounds, organic compounds, and their mixtures were used as PCMs, which can be further classified into inorganic PCMs and organic PCMs, such as paraffin waxes, fatty acids, polyhydric alcohol, and $n$-alkanes [17]. In general, inorganic PCMs have some unavoidable shortages used in the TES systems, such as their supercooling trend, toxicity, corrosivity, and ecologically harmful properties. On the contrary, most of the organic PCMs are safe, noncorrosive, inexpensive, and chemically inert and have no phase segregation. Among them, the paraffin waxes are the most popular due to the remarkable properties, such as high energy storage density, low vapor pressure, small degree of supercooling, nontoxicity, and commercial availability at a relatively low cost [97]. 


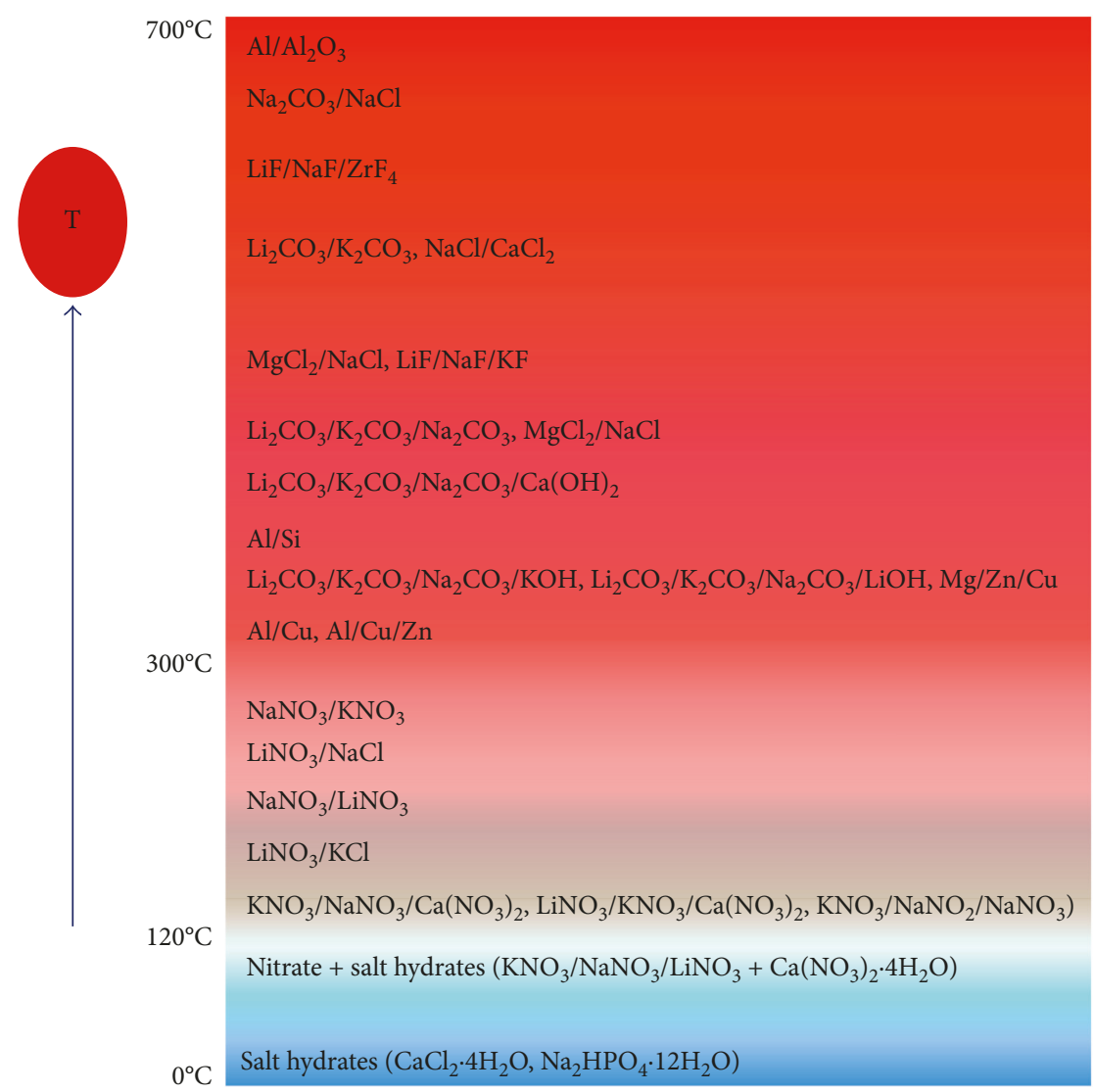

FIgURE 1: The relationship of the melting point and inorganic PCMs.

Meanwhile, fatty acids have also many advantages for the TES system due to the high latent heat, little volume change during phase change process, little supercooling, nontoxicity, and moderate price.

Some study of thermal properties focus on the paraffin wax as PCM by researchers. In this study, Yang et al. [97] selected the paraffin wax with the melting temperature of $50-52^{\circ} \mathrm{C}$ and the latent heat of $220.3 \mathrm{~J} / \mathrm{g}$ as the PCM for preparing the composites. As presented in DSC plots, the latent heat and melting point were found to be $110.15 \mathrm{~J} / \mathrm{g}$ and $46-48^{\circ} \mathrm{C}$ for paraffin/rude-Pal; $124.52 \mathrm{~J} / \mathrm{g}$ and $50-52^{\circ} \mathrm{C}$ for paraffin/rinsed-Pal; $132.18 \mathrm{~J} / \mathrm{g}$ and $54-56^{\circ} \mathrm{C}$ for paraffin/ $\mathrm{H}^{-}$-Pal; and $120.16 \mathrm{~J} / \mathrm{g}$ and $50-52^{\circ} \mathrm{C}$ for paraffin/organic-Pal. The composites of graphite-paraffin with different mass fraction were elaborated by Fethi et al. [98]. And the latent heat and melting point were measured using the DSC. It can be seen that the melting point of the composite $20 \%$ graphite-paraffin $\left(57.21^{\circ} \mathrm{C}\right)$ was slightly different compared with the pure paraffin $\left(58^{\circ} \mathrm{C}\right)$.

Recently, the fatty acids as the very popular PCMs have been investigated. Ke [99] selected fatty acids including capric acid (CA), lauric acid (LA), myristic acid (MA), palmitic acid (PA), and stearic acid (SA) as the PCMs. According to the DSC curves, the developed binary and multiple fatty acid eutectics exhibited desired latent heat ranging from about $130 \mathrm{~J} / \mathrm{g}$ to $200 \mathrm{~J} / \mathrm{g}$, and their onset melting temperatures were in the range of about $14-53^{\circ} \mathrm{C}$. Fauzi et al. [100] researched the thermal properties of both binary mixtures of fatty acid, myristic acid/palmitic acid/sodium myristate, and myristic acid/palmitic acid/sodium palmitate (MA/PA/SP) as the PCMs. From the DSC plots, the melting points of two kinds of binary mixtures were $41.36^{\circ} \mathrm{C}$ and $41.58^{\circ} \mathrm{C}$, respectively, with the latent heat of $179.12 \mathrm{~J} / \mathrm{g}$ and $184.14 \mathrm{~J} / \mathrm{g}$.

The researchers have studied the effect of a lot of supporting materials (such as diatomite, expanded vermiculite, and bentonite) on fatty acids. In this study, Tang et al. [101] prepared the shape-stabilized fatty acid eutectics, such as palmitic acid (PA), capric acid (CA), and diatomite (as the supporting material) composites. The melting points and latent heat of the PA and $\mathrm{CA}$ were $62.89^{\circ} \mathrm{C}, 32.19^{\circ} \mathrm{C}$ and $208.78 \mathrm{~J} / \mathrm{g}, 159.97 \mathrm{~J} / \mathrm{g}$, respectively. The DSC results showed that the composite (PA/CA-diatomite) melts at $26.69^{\circ} \mathrm{C}$ with a latent heat of $98.26 \mathrm{~J} / \mathrm{g}$. Jiesheng et al. [102] and Wen et al. [103] investigated the thermal properties of the composite PCM lauric acid-expanded perlite (LA-EP) with expanded vermiculite (EVM) as the supporting material. The results of DSC analysis showed that the melting point and latent heat of the composites of LA-EP and LA-EVM were $43.2^{\circ} \mathrm{C}$, $41.88^{\circ} \mathrm{C}$ and $105.58 \mathrm{~J} / \mathrm{g}, 126.8 \mathrm{~J} / \mathrm{g}$, respectively. Fauzi et al. [104] studied the fatty acid of myristic acid/palmitic acid/sodium palmitate (MA/PA/SP) and myristic acid/palmitic acid/sodium stearate (MA/PA/SS), and Shorea javanica (SJ) was used as a porous material. The latent heat and melting point were $169.71 \mathrm{~J} / \mathrm{g}, 172.72 \mathrm{~J} / \mathrm{g}$ and $40.13^{\circ} \mathrm{C}$, $41.65^{\circ} \mathrm{C}$, respectively. In this work, capric acid-expanded 
perlite (CA-EP) and capric/stearic acid-expanded perlite (CA/SA-EP) composite PCMs were prepared. Wei et al. [105] found that the latent heat of CA-EP composites was $87.3 \mathrm{~J} / \mathrm{g}$ with the melting point at $33.6^{\circ} \mathrm{C}$. And the corresponding value of the CA/SA-EP was $82.1 \mathrm{~J} / \mathrm{g}$. Huang et al. [106] investigated the thermal properties of palmitic acid/stearic acid (PA/SA) eutectic mixtures as PCM and the bentonite as the supporting material. And the melting temperature of the eutectic was $53.64^{\circ} \mathrm{C}$ with the latent heat of $189.47 \mathrm{~J} / \mathrm{g}$.

And $n$-alkanes and polyhydric alcohol as the PCMs utilized in the TES system have been studied in recent years. Xiong et al. [107] prepared the composite of polyethylene glycol-graphene oxide (PEG4000-GO). For pure PEG4000, the melting point and latent heat are $65^{\circ} \mathrm{C}$ and $182.8 \mathrm{~J} / \mathrm{g}$ during the melting process. And the melting point and latent heat of this composite were $62.2^{\circ} \mathrm{C}$ and $174.5 \mathrm{~J} / \mathrm{g}$, which were slightly lower compared with the pure PEG. Zhang et al. [108] studied the thermal properties of polyethylene glycolexpanded perlite (PEG-EP) composite with carbon layer PCMs. The results indicated that the values for the latent heat and melting point of the composite during melting were $134.93 \mathrm{~J} / \mathrm{g}$ and $55.19^{\circ} \mathrm{C}$, respectively. Zhang et al. [109] selected the PEG as the latent heat storage material, and graphene oxide-based mesoporous silica sheets (GOS) were prepared as supporting materials. Combined with DSC results, it was found that the melting point of composite PCMs was slightly higher than that of the pure PEG $\left(46.26^{\circ} \mathrm{C}\right)$. When the PEG mass fractions were between $60 \%$ and $80 \%$, the latent heat of composites were 61.32 $136.30 \mathrm{~J} / \mathrm{g}$. Tang et al. [110] studied the thermal properties of the stable composite $\mathrm{Ti}_{4} \mathrm{O}_{7} / \mathrm{PEG} / \mathrm{SiO}_{2}$ by DSC. The results indicated that the melting point of $\mathrm{Ti}_{4} \mathrm{O}_{7} / \mathrm{PEG} / \mathrm{SiO}_{2}$ was close to the pure PEG6000 $\left(61.4^{\circ} \mathrm{C}\right)$. The latent heat was $129.8 \mathrm{~J} / \mathrm{g}$ for $\mathrm{Ti}_{4} \mathrm{O}_{7}(3 \%) / \mathrm{PEG} / \mathrm{SiO}_{2}$ with the melting point of $59.8^{\circ} \mathrm{C}$. In this research, Yang et al. [111] selected the highdensity polyethylene (HDPE) as the PCM for mediumtemperature TES application. The DSC curve results show that the composite of HDPE-graphite melts at $139.1^{\circ} \mathrm{C}$ with the latent heat of $130.7 \mathrm{~J} / \mathrm{g}$ while the pure HDPE melts at $137^{\circ} \mathrm{C}$ with the latent heat of $172.7 \mathrm{~J} / \mathrm{g}$. Tang et al. [112] selected the PA/HDPE and graphene nanoplatelets (GNP) as solid-liquid PCM and nanoadditives. The DSC result showed that the PA/HDPE-GNP had the high latent heat of $157.82 \mathrm{~J} / \mathrm{g}$ and constant melting point of around $62^{\circ} \mathrm{C}$.

A shape-stabilized octadecane and $\mathrm{SiO}_{2}$ microcapsules were prepared by using the sol-gel method, and the octadecane was selected as PCM for TES. Tang et al. [113] adopted DSC to measure the thermal properties of the microcapsules. The results showed that the satisfactory microencapsulated phase change material (MPCM) sample melts at $28.32^{\circ} \mathrm{C}$ with a latent heat of $227.66 \mathrm{~J} / \mathrm{g}$. Xu et al. [114] selected a composite of pure D-mannitol $\left(\mathrm{C}_{6} \mathrm{H}_{14} \mathrm{O}_{6}\right)$ with a melting point of $166-169^{\circ} \mathrm{C}$ as PCM and EG as encapsulation heat transfer promoter. From the DSC plots, the melting point slightly shifts from $164.87^{\circ} \mathrm{C}$ of pure $\mathrm{D}$-mannitol to $151.82^{\circ} \mathrm{C}$ of composite PCM. And the latent heat of pure D-mannitol and composite was $319.0 \mathrm{~J} / \mathrm{g}$ and 267.7 J/g. Rodríguez and López [115] selected pluronic F127
TABLE 7: The melting point of organic eutectic composites.

\begin{tabular}{lcc}
\hline Temperature $\left({ }^{\circ} \mathrm{C}\right)$ & Compound & References \\
\hline Paraffin & {$[97,98]$} \\
PA/CA & {$[101]$} \\
LA & {$[102,103]$} \\
MA/PA/SP & {$[104]$} \\
CA/SA & {$[105]$} \\
& LA/PA, LA/MA/SA & {$[99]$} \\
CA/LA/PA/SA & {$[99]$} \\
$0-60$ & CA/LA/MA/PA/SA & {$[99]$} \\
MA/PA/SM & {$[100]$} \\
PA/SA & {$[106]$} \\
PEG & {$[107,109,110]$} \\
& PEP, PEPC & {$[108]$} \\
HE/LA & {$[116]$} \\
& Octadecane & {$[113]$} \\
\hline $60-120$ & PA & {$[101]$} \\
& PEG & {$[107,110]$} \\
& HDPE/PA & {$[112]$} \\
$120-180$ & HDPE & {$[118]$} \\
\hline \multirow{2}{*}{12 Eritol/xylitol/sorbitol } & {$[111]$} \\
& D-mannitol & {$[114]$} \\
\hline
\end{tabular}

TABLE 8: The latent heat of organic eutectic composites.

\begin{tabular}{lcc}
\hline Latent heat (J/g) & Compound & References \\
\hline $0-100$ & CA-EP, CA/SA-EP & {$[105]$} \\
PA/SA-bentonite & {$[106]$} \\
\hline Paraffin & {$[97,98]$} \\
PA/CA & {$[101]$} \\
LA & {$[102,103]$} \\
& MA/PA/SP-SJ, MA/PA/SS-SJ & {$[104]$} \\
LA/MA, CA/LA/PA & {$[99]$} \\
CA/LA/MA/PA/SA & {$[99]$} \\
MA/PA/SM, MA/PA/SM & {$[100]$} \\
PA/SA & {$[106]$} \\
& PEG & {$[107,109,110]$} \\
& PEP, PEPC & {$[108]$} \\
HDPE & {$[111]$} \\
& Erythritol/sorbitol & {$[118]$} \\
& Xylitol/sorbitol & {$[118]$} \\
\hline $200-300$ & PEG6000 & {$[110]$} \\
& Octadecane-silica & {$[113]$} \\
& D-mannitol-EG & {$[114]$} \\
$300-400$ & Erythritol/xylitol & {$[118]$} \\
\hline
\end{tabular}

as a PCM, and the DSC results indicated that the melting point of $\mathrm{F} 127$ is $54^{\circ} \mathrm{C}$ with the latent heat of $102 \mathrm{~J} / \mathrm{g}$. Han et al. [116] chose the eutectic mixture of 1,6-hexanediol/lauric acid (HE/LA) as PCM. And the DSC curve displayed the melting point of $36.92^{\circ} \mathrm{C}$ as well as a heat of fusion of $177.11 \mathrm{~J} / \mathrm{g}$.

In recent years, the sugar alcohols as the PCMs were very promising in the application of the TES system due to their high storage capacity, safety, and economic cost. Solé et al. [117] analyzed two samples of each sugar alcohol (D-mannitol and myoinositol). The DSC results indicated that the melting point and latent heat for both samples were $179.9^{\circ} \mathrm{C}, 180.34^{\circ} \mathrm{C}$ and $246.4 \mathrm{~J} / \mathrm{g}, 267.9 \mathrm{~J} / \mathrm{g}$, respectively. 
And Diarce et al. [118] investigated the new binary eutectic mixtures of sugar alcohols in the temperature range of $50-90^{\circ} \mathrm{C}$. The mixtures were composed of erythritol-xylitol, erythritol-sorbitol, and xylitol-sorbitol. According to the DSC plots, the melting points of these mixtures were $83.9^{\circ} \mathrm{C}$, $86.6^{\circ} \mathrm{C}$, and $74.9^{\circ} \mathrm{C}$, respectively. And the erythritol-xylitol eutectic PCM showed the largest latent heat of $248.7 \mathrm{~J} / \mathrm{g}$. Meanwhile, the latent heat for the erythritol-sorbitol and xylitol-sorbitol eutectic compositions was found to be $172.8 \mathrm{~J} / \mathrm{g}$ and $169.6 \mathrm{~J} / \mathrm{g}$, respectively.

In the above literatures, the main works focus on the research of phase change temperature and latent heat of organic PCMs via DSC. It can be seen that the organic PCMs, such as paraffin waxes, fatty acids, polyhydric alcohol, and $n$-alkanes, are the very promising materials with a lot of advantages for satisfying the demand of low-medium temperature applications. In addition, the summary of the melting point and latent heat of involved organic eutectic composites is displayed in Tables 7 and 8, respectively, and generally, it can be seen that the organic materials as the PCMs are used in low-medium temperature TES applications.

\section{Conclusions}

Investigations on thermal energy storage (TES) system have developed over the past four decades and are ongoing. Especially, the PCM is currently one of the most promising elements to research the TES system, and the desirable PCMs need some thermal properties, such as suitable melting point, high latent heat, high thermal conductivity, and high specific heat. Therefore, this paper reviews the melting point and latent heat of PCMs via the differential scanning calorimetry (DSC) in order to obtain the suitable PCM for TES applications. There is a series of PCMs with different phase change temperatures via DSC to assist the selection of PCM in the TES system which has been investigated and reviewed. The following conclusions can be reported:

(1) According to the above analysis of the literatures in this paper, it can be seen that the PCMs can be classified into organic materials (such as paraffin waxes, fatty acids, polyhydric alcohol, and $n$-alkanes) and inorganic materials based on the chemical composition.

(2) On the basis of melting point of the inorganic PCMs, they can be divided into three groups: low-temperature heat storage $\left(<120^{\circ} \mathrm{C}\right)$, medium-temperature heat storage $\left(120-300^{\circ} \mathrm{C}\right)$, and high-temperature heat storage $\left(>300^{\circ} \mathrm{C}\right)$. For the solar TES system, the medium-high temperature PCMs are the most popular material.

(3) According to the phase change temperature of the organic PCMs, it is found that the organic PCM is very promising materials with many advantages for satisfying the demand of low-temperature applications.

(4) The melting point and latent heat of the PCM have been analyzed and summarized, which are the key to select and utilize the suitable PCM in the TES applications. However, the types of PCMs are not enough to satisfy the optional utilization in the TES applications at present. In later work, in order to supply perfect thermal properties of PCMs, the better characteristics of PCMs need to be investigated. And it will provide a more significant reference and guidance for the TES applications.

\section{Nomenclature}

DSC: Differential scanning calorimetry

CSP: Concentrating solar power

LHTES: Latent heat thermal energy storage

PCMs: Phase change materials

TES: Thermal energy storage

HTF: Heat transfer fluid

DTA: Differential thermal analysis

PTC: Parabolic tough collector

EHS: Eutectic hydrated salt.

\section{Conflicts of Interest}

The authors declare that they have no conflicts of interest.

\section{Acknowledgments}

This work was supported by the National Natural Science Foundation of China (no. 51406033).

\section{References}

[1] M. Kenisarin, "High-temperature phase change materials for thermal energy storage," Renewable and Sustainable Energy Reviews, vol. 14, no. 3, pp. 955-970, 2010.

[2] G. Li, Q. Xuan, G. Pei, Y. Su, and J. Ji, "Effect of non-uniform illumination and temperature distribution on concentrating solar cell-a review," Energy, vol. 144, pp. 1119-1136, 2018.

[3] F. Wang, Y. Shuai, H. Tan, and C. Yu, "Thermal performance analysis of porous media receiver with concentrated solar irradiation," International Journal of Heat and Mass Transfer, vol. 62, pp. 247-254, 2013.

[4] Q. Mao, Y. Shuai, and Y. Yuan, "Study on radiation flux of the receiver with a parabolic solar concentrator system," Energy Conversion and Management, vol. 84, pp. 1-6, 2014.

[5] A. Regin, S. Solanki, and J. Saini, "Heat transfer characteristics of thermal energy storage system using PCM capsules: a review," Renewable and Sustainable Energy Reviews, vol. 12, no. 9, pp. 2438-2458, 2008.

[6] Q. Mao, L. Zhang, H. Wu, and X. Liu, "Design and calculation of a new storage tank for concentrating solar power plant," Energy Conversion and Management, vol. 100, pp. 414-418, 2015.

[7] A. Gil, M. Medrano, I. Martorell, A. Lázaro, P. Dolado, and B. Zalba, "State of the art on high temperature thermal energy storage for power generation. Part 1-concepts, materials and modellization," Renewable and Sustainable Energy Reviews, vol. 14, no. 1, pp. 31-55, 2010.

[8] A. Sharma, V. Tyagi, C. Chen, and D. Buddhi, "Review on thermal energy storage with phase change materials and application," Renewable and Sustainable Energy Reviews, vol. 13, no. 2, pp. 318-345, 2009. 
[9] Q. Mao, H. Chen, Y. Zhao, and H. Wu, "A novel heat transfer model of a phase change material using in solar power plant," Applied Thermal Engineering, vol. 129, pp. 557-563, 2018.

[10] S. Kuravi, J. Trahan, D. Goswami, M. Rahman, and E. Stefanakos, "Thermal energy storage technologies and systems for concentrating solar power plants," Progress in Energy and Combustion Science, vol. 39, no. 4, pp. 285-319, 2013.

[11] B. Cárdenas and N. León, "High temperature latent heat thermal energy storage: phase change materials, design considerations and performance enhancement techniques," Renewable and Sustainable Energy Reviews, vol. 27, pp. 724-737, 2013.

[12] S. Jegadheeswaran and S. Pohekar, "Performance enhancement in latent heat thermal storage system: a review," Renewable and Sustainable Energy Reviews, vol. 13, no. 9, pp. 2225-2244, 2009.

[13] F. Agyenim, N. Hewitt, P. Eames, and M. Smyth, "A review of materials, heat transfer and phase change problem formulation for latent heat thermal energy storage system (LHTESS)," Renewable and Sustainable Energy Reviews, vol. 14, no. 2, pp. 615-628, 2010.

[14] P. Pinel, C. Cruickshank, I. Beausoleil-Morrwason, and A. Wills, "A review of available methods for seasonal storage of solar thermal energy in residential application," Renewable and Sustainable Energy Reviews, vol. 15, no. 7, pp. 3341-3359, 2011.

[15] A. Al-abidi, S. Mat, K. Sopian, M. Sulaiman, and A. Mohammed, "CFD applications for latent heat thermal energy storage: a review," Renewable and Sustainable Energy Reviews, vol. 20, pp. 353-363, 2013.

[16] A. Jamekhorshid, S. Sadrameli, and M. Farid, "A review of microencapsulation methods of phase change materials (PCMs) as a thermal energy storage (TES) medium," Renewable and Sustainable Energy Reviews, vol. 31, pp. 531-542, 2014.

[17] M. K. Rathod and J. Banerjee, "Thermal stability of phase change materials used in latent heat energy storage system: a review," Renewable and Sustainable Energy Reviews, vol. 18, pp. 246-258, 2013.

[18] G. Fang, F. Tang, and L. Cao, "Preparation, thermal properties and applications of shape-stabilized thermal energy storage materials," Renewable and Sustainable Energy Reviews, vol. 40, pp. 237-259, 2014.

[19] P. Verma, Varun, and S. Singal, "Review of mathematical modeling on latent heat thermal energy storage system using phase-change material," Renewable and Sustainable Energy Reviews, vol. 12, no. 4, pp. 999-1031, 2008.

[20] N. Soweres, J. Costa, A. Gaspar, and P. Santos, "Review of passive PCM latent heat thermal energy storage systems towards buildings' energy efficiency," Energy and Building, vol. 59, pp. 82-103, 2013.

[21] M. Liu, W. Saman, and F. Bruno, "Review on storage materials and thermal performance enhancement techniques for high temperature phase change thermal storage systems," Renewable and Sustainable Energy Reviews, vol. 16, no. 4, pp. 2118-2132, 2012.

[22] C. Corgnale, B. Hardy, T. Motyka, and R. Zidan, "Screening analysis of metal hydride based thermal energy storage systems for concentrating solar power plants," Renewable and Sustainable Energy Reviews, vol. 38, pp. 821-833, 2014.

[23] M. Medrano, A. Gil, I. Martorell, and X. Potau, "State of the art on high temperature thermal energy storage for power generation. Part 2-case studies," Renewable and Sustainable Energy Reviews, vol. 14, no. 1, pp. 56-72, 2010.
[24] T. Yan, R. Wang, T. Li, L. Wang, and I. Fred, "A review of promising candidate reactions for chemical heat storage," $R e$ newable and Sustainable Energy Reviews, vol. 43, pp. 13-31, 2015.

[25] J. Xu, R. Wang, and Y. Li, "A review of available technologies for seasonal thermal energy storage," Solar Energy, vol. 103, pp. 610-638, 2014.

[26] Y. Tian and C. Zhao, "A review of solar collectors and thermal energy storage in solar thermal applications," Applied Energy, vol. 104, pp. 538-553, 2013.

[27] D. Aydin, S. Casey, and S. Riffat, "The latent advancements on thermochemical heat storage systems," Renewable and Sustainable Energy Reviews, vol. 41, pp. 356-367, 2015.

[28] P. Pardo, A. Deydier, Z. Anxionnaz-Minvielle, S. Rougé, M. Cabassud, and P. Cognet, "A review on high temperature thermochemical heat energy storage," Renewable and Sustainable Energy Reviews, vol. 32, pp. 591-610, 2014.

[29] S. Mua, J. Guo, Y. Yu, and Q. A. Zhang, "Synthesis and thermal properties of cross-linked poly (acrylonitrile-coitaconate)/polyethylene glycol as novel form-stable change material," Energy Conversion and Management, vol. 110, pp. 176-183, 2016.

[30] S. Ahmed, M. Khalid, W. Rashmi, and A. Chan, "Recent progress in solar thermal energy storage using nanomaterials," Renewable and Sustainable Energy Reviews, vol. 67, pp. 450-460, 2017.

[31] A. Lele and J. Tamba, "A review on the use of $\mathrm{SrBr}_{2} \cdot 6 \mathrm{H}_{2} \mathrm{O}$ as a potential material for low temperature energy storage systems and building applications," Solar Energy Materials and Solar Cells, vol. 164, pp. 175-187, 2017.

[32] V. Nunes, C. Queirós, M. Lourenço, F. J. V. Santos, and C. A. N. de Castro, "Molten salts as engineering fluids-a review part I. Molten alkali nitrates," Applied Energy, vol. 183, pp. 603-611, 2016.

[33] Z. Zhao and M. Arif, "Solar thermal energy with molten-salt storage for residential heating application," Energy Procedia, vol. 110, pp. 243-249, 2017.

[34] H. Riazi, T. Murphy, G. B. Webber, R. Atkin, S. S. M. Tehrani, and R. A. Taylor, "Specific heat control of nanofluids: a critical review," International Journal of Thermal Sciences, vol. 107, pp. 25-38, 2016.

[35] K. Vignarooban, X. Xu, A. Arvay, K. Hsu, and A. M. Kannan, "Heat transfer fluids for concentrating solar power systems-a review," Applied Energy, vol. 146, pp. 383-396, 2015.

[36] D. Nkwetta and F. Haghighat, "Thermal energy storage with phase change material-a state-of-the art review," Sustainable Cities and Society, vol. 10, pp. 87-100, 2014.

[37] Q. Mao, "Recent developments in geometrical configurations of thermal energy storage for concentrating solar power plant," Renewable and Sustainable Energy Reviews, vol. 59, pp. 320-327, 2016.

[38] S. Mohamed, F. Al-Sulaiman, N. Ibrahim et al., "A review on current status and challenges of inorganic phase change materials for thermal energy storage systems," Renewable and Sustainable Energy Reviews, vol. 70, pp. 1072-1089, 2017.

[39] S. Drwassi, A. Eddhahak, S. Caré, and J. Neji, "Thermal analysis by DSC of phase change materials, study of the damage effect," Journal of Building Engineering, vol. 1, pp. 13-19, 2015.

[40] L. Li, H. Yu, X. Wang, and S. Zheng, "Thermal analysis of melting and freezing processes of phase change materials (PCMs) based on dynamic DSC test," Energy and Buildings, vol. 130, pp. 388-396, 2016.

[41] Y. Wu, Y. Li, Y. Lu, and H. Wang, "Novel low melting point binary nitrates for thermal energy storage applications," 
Solar Energy Materials and Solar Cells, vol. 164, pp. 114-121, 2017.

[42] Z. Jiang, G. Leng, F. Ye, Z. Ge, and C. Liu, "Form-stable $\mathrm{LiNO}_{3}-\mathrm{NaNO}_{3}-\mathrm{KNO}_{3}-\mathrm{Ca}\left(\mathrm{NO}_{3}\right)_{2} /$ calcium silicate composite phase change material (PCM) for mid-low temperature thermal energy storage," Energy Conversion and Management, vol. 106, pp. 165-172, 2015.

[43] Y. Wu, Y. Li, N. Ren, and C. Ma, "Improving the thermal properties of $\mathrm{NaNO}_{3}-\mathrm{KNO}_{3}$ for concentrating solar power by adding additives," Solar Energy Materials and Solar Cells, vol. 160, pp. 263-268, 2017.

[44] N. Ren, Y. Wu, C. Ma, and L. Sang, "Preparation and thermal properties of quaternary mixed nitrate with low melting point," Solar Energy Materials and Solar Cells, vol. 127, pp. 6-13, 2014.

[45] Y. Chen and C. Zhao, "Thermophysical properties of $\mathrm{Ca}$ $\left(\mathrm{NO}_{3}\right)_{2}-\mathrm{NaNO}_{3}-\mathrm{KNO}_{3}$ mixtures for heat transfer and thermal storage," Solar Energy, vol. 146, pp. 172-179, 2017.

[46] C. Zhao and $\mathrm{Z}$. Wu, "Thermal property characterization of a low melting-temperature ternary nitrate salt mixture for thermal energy storage systems," Solar Energy Materials and Solar Cells, vol. 95, no. 12, pp. 3341-3346, 2011.

[47] F. Roget, C. Favotto, and J. Rogez, "Study of the $\mathrm{KNO}_{3}$ $\mathrm{LiNO}_{3}$ and $\mathrm{KNO}_{3}-\mathrm{NaNO}_{3}-\mathrm{LiNO}_{3}$ eutectics as phase change materials for thermal storage in a low-temperature solar power plant," Solar Energy, vol. 95, pp. 155-169, 2013.

[48] T. Wang, D. Mantha, and R. Reddy, "Thermal stability of the eutectic composition in $\mathrm{LiNO}_{3}-\mathrm{NaNO}_{3}-\mathrm{KNO}_{3}$ ternary system used for thermal energy storage," Solar Energy Materials and Solar Cells, vol. 100, pp. 162-168, 2012.

[49] D. Mantha, T. Wang, and R. Reddy, "Thermodynamic modeling of eutectic point in the $\mathrm{LiNO}_{3}-\mathrm{NaNO}_{3}-\mathrm{KNO}_{3}-\mathrm{NaNO}_{3}$ quaternary system," Solar Energy Materials and Solar Cells, vol. 118, pp. 18-21, 2013.

[50] Y. Liu and Y. Yang, "Preparation and thermal properties of $\mathrm{Na}_{2} \mathrm{CO}_{3} \cdot 10 \mathrm{H}_{2} \mathrm{O}-\mathrm{Na}_{2} \mathrm{HPO}_{4} \cdot 12 \mathrm{H}_{2} \mathrm{O}$ eutectic hydrate salt as a novel phase change material for energy storage," Applied Thermal Engineering, vol. 112, pp. 606-609, 2017.

[51] H. Schmit, W. Pfeffera, C. Rathgebera, and S. Hieblera, "Experimental investigation of the concentration dependent maximum storage capacity of two inorganic phase change materials," Energy Procedia, vol. 73, pp. 231-238, 2015.

[52] H. Schmit, S. Pöllinger, W. Pfeffer, and S. Hiebler, "Calorimetric and theoretical determination of the concentration dependent enthalpy change around $\mathrm{CaBr}_{2} \cdot 6 \mathrm{H}_{2} \mathrm{O}$," Thermochimica Acta, vol. 609, pp. 20-30, 2015.

[53] H. Schmit, W. Pfeffer, C. Rathgeber, and S. Bavarian, "Calorimetric investigation of the concentration dependent enthalpy change around semi-congruent melting $\mathrm{CaCl}_{2} \cdot 6 \mathrm{H}_{2} \mathrm{O}$," Thermochimica Acta, vol. 635, pp. 26-33, 2016.

[54] S. Ushak, "Characterization of calcium chloride tetrahydrate as a phase change material and thermodynamic analysis of the results," Renewable Energy, vol. 95, pp. 213-224, 2016.

[55] Y. Wu and T. Wang, "Hydrated salts/expanded graphite composite with high thermal conductivity as a shapestabilized phase change material for thermal energy storage," Energy Conversion and Management, vol. 101, pp. 164-171, 2015.

[56] H. Schmit, C. Rathgeber, P. Hennemann, and S. Hiebler, "Three-step method to determine the eutectic composition of binary and ternary mixtures tested on two novel eutectic phase change materials based on salt hydrates," Journal of Thermal Analysis and Calorimetry, vol. 117, no. 2, pp. 595-602, 2014.
[57] J. Huang, T. Wang, P. Zhu, and J. Xiao, "Preparation, characterization, and thermal properties of the microencapsulation of a hydrated salt as phase change energy storage materials," Thermochimica Acta, vol. 557, pp. 1-6, 2013.

[58] Y. Wu and T. Wang, "Preparation and characterization of hydrated salts/silica composite as shape-stabilized phase change material via sol-gel process," Thermochimica Acta, vol. 591, pp. 10-15, 2014.

[59] Y. Liu and Y. Yang, "Use of nano-a- $\mathrm{Al}_{2} \mathrm{O}_{3}$ to improve binary eutectic hydrated salt as phase change material," Solar Energy Materials and Solar Cells, vol. 160, pp. 18-25, 2017.

[60] D. Zhou and P. Eames, "Thermal characterization of binary sodium/lithium nitrate salts for latent heat storage at medium temperatures," Solar Energy Materials and Solar Cells, vol. 157, pp. 1019-1025, 2016.

[61] J. Xiao, J. Huanga, P. Zhu, and C. Wang, "Preparation, characterization and thermal properties of binary nitrate salts/expanded graphite as composite phase change material," Thermochimica Acta, vol. 587, pp. 52-58, 2014.

[62] Y. Li, B. Guo, G. Huang, S. Kubo, and P. Shu, "Characterization and thermal performance of nitrate mixture/SiC ceramic honeycomb composite phase change materials for thermal energy storage," Applied Thermal Engineering, vol. 81, pp. 193-197, 2015.

[63] Y. Luo, X. Du, A. Awad, and D. Wen, “Thermal energy storage enhancement of a binary molten salt via in-situ produced nanoparticles," International Journal of Heat and Mass Transfer, vol. 104, pp. 658-664, 2017.

[64] P. Myers, T. Alam, R. Kamal, D. Y. Goswami, and E. Stefanakos, "Nitrate salts doped with $\mathrm{CuO}$ nanoparticles for thermal energy storage with improved heat transfer," Applied Energy, vol. 165, pp. 225-233, 2016.

[65] G. Xu, G. Leng, C. Yang et al., "Sodium nitrate-diatomite composite materials for thermal energy storage," Solar Energy, vol. 146, pp. 494-502, 2017.

[66] A. Fernández, S. Ushak, H. Galleguillos, and F. Pérez, "Thermal characterisation of an innovative quaternary molten nitrate mixture for energy storage in CSP plants," Solar Energy Materials and Solar Cells, vol. 132, pp. 172-177, 2015.

[67] A. Fernández, S. Ushak, H. Galleguillos, and F. Pérez, "Development of new molten salts with $\mathrm{LiNO}_{3}$ and $\mathrm{Ca}$ $\left(\mathrm{NO}_{3}\right)_{2}$ for energy storage in CSP plants," Applied Energy, vol. 119, pp. 131-140, 2014.

[68] M. Mohammad, G. Brooks, and M. Rhamdhani, “Thermal analysis of molten ternary lithium-sodium-potassium nitrates," Renewable Energy, vol. 104, pp. 76-87, 2017.

[69] K. Pramod, P. Rao, N. Choudary, and K. Ramesh, "Novel methodology to prepare homogenous ternary molten salts for concentrated solar power applications and their thermophysical characterization," Applied Thermal Engineering, vol. 109, pp. 906-910, 2016.

[70] Z. Li and Z. Wu, "Development of medium-temperature composite phase change material with high thermal stability and conductivity," Solar Energy Materials and Solar Cells, vol. 155, pp. 341-347, 2016.

[71] Z. Huang, X. Gao, T. Xu, Y. Fang, and Z. Zhang, "Thermal property measurement and heat storage analysis of $\mathrm{LiNO}_{3} /$ KCl-expanded graphite composite phase change material," Applied Energy, vol. 115, pp. 265-271, 2014.

[72] Z. Huang, Z. Luo, X. Gao, X. Fang, Y. Fang, and Z. Zhang, "Investigations on the thermal stability, long-term reliability of $\mathrm{LiNO}_{3} / \mathrm{KCl}$-expanded graphite composite as industrial 
waste heat storage material and its corrosion properties with metals," Applied Energy, vol. 188, pp. 521-528, 2017.

[73] L. Zhong, X. Zhang, Y. Luan, G. Wang, Y. Feng, and D. Feng, "Preparation and thermal properties of porous heterogeneous composite phase change materials based on molten salts/expanded graphite," Solar Energy, vol. 107, pp. 63-73, 2014.

[74] D. Zhou and P. Eames, "A study of a eutectic salt of lithium nitrate and sodium chloride (87-13\%) for latent heat storage," Solar Energy Materials and Solar Cells, vol. 167, pp. 157-161, 2017.

[75] Q. Peng, J. Ding, X. Wei, and G. Jiang, "Prediction of the eutectic mixture formation of monovalent cation ternary salt mixture based on theoretical modeling and differential scanning calorimeter method," Thermochimica Acta, vol. 654, pp. 28-34, 2017.

[76] Q. Peng, J. Ding, X. Wei, J. Yang, and X. Yang, "The preparation and properties of multi-component molten salts," Applied Energy, vol. 87, no. 9, pp. 2812-2817, 2010.

[77] Q. Peng, X. Yang, J. Ding, X. Wei, and J. Yang, "Design of new molten salt thermal energy storage material for solar thermal power plant," Applied Energy, vol. 112, pp. 682-689, 2013.

[78] H. Tian, W. Wang, J. Ding, X. Wei, and C. Huang, "Preparation of binary eutectic chloride/expanded graphite as high-temperature thermal energy storage materials," Solar Energy Materials and Solar Cells, vol. 149, pp. 187-194, 2016.

[79] M. Liu, J. Gomez, C. Turchi, N. H. S. Tay, W. Saman, and F. Bruno, "Determination of thermo-physical properties and stability testing of high-temperature phase-change materials for CSP applications," Solar Energy Materials and Solar Cells, vol. 139, pp. 81-87, 2015.

[80] L. Sang, M. Cai, Y. Zhao, N. Ren, Y. Wu, and C. Burda, "Mixed metal carbonates/hydroxides for concentrating solar power analyzed with DSC and XRD," Solar Energy Materials and Solar Cells, vol. 140, pp. 167-173, 2015.

[81] Y. Wu, N. Ren, T. Wang, and C. Ma, "Experimental study on optimized composition of mixed carbonate salt for sensible heat storage in solar thermal power plant," Solar Energy, vol. 85, no. 9, pp. 1957-1966, 2011.

[82] Y. Jiang, Y. Sun, F. Bruno, and S. Li, "Thermal stability of $\mathrm{Na}_{2} \mathrm{CO}_{3}-\mathrm{Li}_{2} \mathrm{CO}_{3}$ as a high temperature phase change material for thermal energy storage," Thermochimica Acta, vol. 650, pp. 88-94, 2017.

[83] S. Omran, P. Heggs, and Y. Ding, "The influence of moisture content on the evaluation of latent heat of molten salts used for thermal energy storage applications," Energy Procedia, vol. 46, pp. 317-323, 2014.

[84] Y. Tao, C. Lin, and Y. He, "Preparation and thermal properties characterization of carbonate salt/carbon nanomaterial composite phase change material," Energy Conversion and Management, vol. 97, pp. 103-110, 2015.

[85] Z. Zhang, Y. Yuan, L. Ouyang et al., "Thermal properties of ternary carbonate/ $\mathrm{T}-\mathrm{ZnOw}$ for thermal energy storage in high-temperature concentrating solar power systems," Composites: Part A, vol. 93, pp. 177-184, 2017.

[86] X. Wei, M. Song, W. Wang, J. Ding, and J. Yang, "Design and thermal properties of a novel ternary chloride eutectics for high-temperature solar energy storage," Applied Energy, vol. 156, pp. 306-310, 2015.

[87] L. Du, J. Ding, H. Tian, W. Wang, X. Wei, and M. Song, "Thermal properties and thermal stability of the ternary eutectic salt $\mathrm{NaCl}-\mathrm{CaCl}_{2}-\mathrm{MgCl}_{2}$ used in high-temperature thermal energy storage process," Applied Energy, vol. 204, pp. 1225-1230, 2017.

[88] V. Khokhlov, I. Korzun, V. Dokutovich, and E. Filatov, "Heat capacity and thermal conductivity of molten ternary lithium, sodium, potassium, and zirconium fluorides mixtures," Journal of Nuclear Materials, vol. 410, no. 1-3, pp. 32-38, 2011.

[89] R. Li, J. Zhu, W. Zhou, X. Cheng, and Y. Li, "Thermal properties of sodium nitrate-expanded vermiculite formstable composite phase change materials," Materials and Design, vol. 104, pp. 190-196, 2016.

[90] R. Li, J. Zhu, W. Zhou, X. Cheng, and Y. Li, "Thermal compatibility of sodium nitrate/expanded perlite composite phase change materials," Applied Thermal Engineering, vol. 103, pp. 452-458, 2016.

[91] L. Sang, M. Cai, N. Ren, Y. Wu, C. Burda, and C. Ma, "Improving the thermal properties of ternary carbonates for concentrating solar power through simple chemical modifications by adding sodium hydroxide and nitrate," Solar Energy Materials and Solar Cells, vol. 124, pp. 61-66, 2014.

[92] T. Wang, D. Mantha, and R. Reddy, "Novel high thermal stability $\mathrm{LiF}-\mathrm{Na}_{2} \mathrm{CO}_{3}-\mathrm{K}_{2} \mathrm{CO}_{3}$ eutectic ternary system for thermal energy storage applications," Solar Energy Materials and Solar Cells, vol. 140, pp. 366-375, 2015.

[93] Y. Jiang, Y. Sun, M. Liu, F. Bruno, and S. Li, "Eutectic $\mathrm{Na}_{2} \mathrm{CO}_{3}-\mathrm{NaCl}$ salt: a new phase change material for high temperature thermal storage," Solar Energy Materials and Solar Cells, vol. 152, pp. 155-160, 2016.

[94] G. Wei, P. Huang, C. Xu et al., "Thermophysical property measurements and thermal energy storage capacity analysis of aluminum alloys," Solar Energy, vol. 137, pp. 66-72, 2016.

[95] L. Yolshina and A. Kvashinchev, "Chemical interaction of liquid aluminum with metal oxides in molten salts," Materials and Design, vol. 105, pp. 124-132, 2016.

[96] E. Rwasueño and A. Faik, "Mg-Zn-Al eutectic alloys as phase change material for latent heat thermal energy storage," Energy Procedia, vol. 69, pp. 1006-1013, 2015.

[97] D. Yang, S. Shi, L. Xiong et al., "Paraffin/palygorskite composite phase change materials for thermal energy storage," Solar Energy Materials and Solar Cells, vol. 144, pp. 228-234, 2016.

[98] A. Fethi, L. Mohamed, K. Mustaphai, B. Tarek, and B. Sassi, "Investigation of a graphite/paraffin phase change composite," International Journal of Thermal Sciences, vol. 88, pp. 128-135, 2015.

[99] H. Ke, "Phase diagrams, eutectic mass ratios and thermal energy storage properties of multiple fatty acid eutectics as novel solid-liquid phase change materials for storage and retrieval of thermal energy," Applied Thermal Engineering, vol. 113, pp. 1319-1331, 2017.

[100] H. Fauzi, H. Metselaar, T. Mahlia, M. Silakhori, and H. C. Ong, "Thermal characteristic reliability of fatty acid binary mixtures as phase change materials (PCMs) for thermal energy storage applications," Applied Thermal Engineering, vol. 80, pp. 127-131, 2015.

[101] F. Tang, D. Su, Y. Tang, and G. Fang, "Synthesis and thermal properties of fatty acid eutectics and diatomite composites as shape-stabilized phase change materials with enhanced thermal conductivity," Solar Energy Materials and Solar Cells, vol. 141, pp. 218-224, 2015.

[102] L. Jiesheng, Y. Yuanyuan, and H. Xiang, "Research on the preparation and properties of lauric acid/expanded perlite phase change materials," Energy and Buildings, vol. 110, pp. 108-111, 2016. 
[103] R. Wen, Z. Huang, Y. Huang et al., "Synthesis and characterization of lauric acid/expanded vermiculite as formstabilized thermal energy storage materials," Energy and Buildings, vol. 116, pp. 677-683, 2016.

[104] H. Fauzi, H. Metselaar, T. Mahlia, H. Ong, Nasruddin, and H. Khanlou, "Preparation and thermal characteristics of eutectic fatty acids/Shorea javanica composite for thermal energy storage," Applied Thermal Engineering, vol. 100, pp. 62-67, 2016.

[105] T. Wei, B. Zheng, J. Liu, Y. Gao, and W. Guo, "Structures and thermal properties of fatty acid/expanded perlite composites as form-stable phase change materials," Energy and Buildings, vol. 68, pp. 587-592, 2014.

[106] X. Huang, G. Alva, L. Liu, and G. Fang, "Preparation, characterization and thermal properties of fatty acid eutectics/bentonite/expanded graphite composites as novel form-stable thermal energy storage materials," Solar Energy Materials and Solar Cells, vol. 166, pp. 157-166, 2017.

[107] W. Xiong, Y. Chen, M. Hao et al., "Facile synthesis of PEG based shape-stabilized phase change materials and their photo-thermal energy conversion," Applied Thermal Engineering, vol. 91, pp. 630-637, 2015.

[108] X. Zhang, R. Wen, C. Tang et al., "Thermal conductivity enhancement of polyethylene glycol/expanded perlite with carbon layer for heat storage application," Energy and Buildings, vol. 130, pp. 113-121, 2016.

[109] L. Zhang, P. Zhang, F. Wang et al., "Phase change materials based on polyethylene glycol supported by graphene-based mesoporous silica sheets," Applied Thermal Engineering, vol. 101, pp. 217-223, 2016.

[110] B. Tang, H. Wei, D. Zhao, and S. Zhang, "Light-heat conversion and thermal conductivity enhancement of $\mathrm{PEG} / \mathrm{SiO}_{2}$ composite PCM by in situ $\mathrm{Ti}_{4} \mathrm{O}_{7}$ doping," Solar Energy Materials and Solar Cells, vol. 161, pp. 183-189, 2017.

[111] C. Yang, M. Navarro, B. Zhao et al., "Thermal conductivity enhancement of recycled high density polyethylene as a storage media for latent heat thermal energy storage," Solar Energy Materials and Solar Cells, vol. 152, pp. 103-110, 2016.

[112] Y. Tang, Y. Jia, G. Alva, X. Huang, and G. Fang, "Synthesis, characterization and properties of palmitic acid/high density polyethylene/grapheme nanoplatelets composites as formstable phase change materials," Solar Energy Materials and Solar Cells, vol. 155, pp. 421-429, 2016.

[113] F. Tang, L. Liu, G. Alva, Y. Jia, and G. Fang, "Synthesis and properties of microencapsulated octadecane with silica shell as shape-stabilized thermal energy storage materials," Solar Energy Materials and Solar Cells, vol. 160, pp. 1-6, 2017.

[114] T. Xu, Q. Chen, G. Huang, Z. Zhang, X. Gao, and S. Lu, "Preparation and thermal energy storage properties of D-mannitol/expanded graphite composite phase change material," Solar Energy Materials and Solar Cells, vol. 155, pp. 141-146, 2016.

[115] F. Rodríguez and B. López, "Phenolic resin/PEO-PPO block copolymer composite materials as phase change materials (PCM) for latent heat thermal energy storage (LHTES)," Journal of Energy Storage, vol. 6, pp. 173-177, 2016.

[116] L. Han, G. Ma, S. Xie, J. Sun, Y. Jia, and Y. Jing, “Thermal properties and stabilities of the eutectic mixture: 1,6hexanediol/lauric acid as a phase change material for thermal energy storage," Applied Thermal Engineering, vol. 116, pp. 153-159, 2017.

[117] A. Solé, H. Neumann, S. Niedermaier, I. Martorell, P. Schossig, and L. F. Cabeza, "Stability of sugar alcohols as PCM for thermal energy storage," Solar Energy Materials and Solar Cells, vol. 126, pp. 125-134, 2014.
[118] G. Diarce, I. Gandarias, Á. Campos-Celador, A. GarcíaRomero, and U. J. Griesser, "Eutectic mixtures of sugar alcohols for thermal energy storage in the $50-90^{\circ} \mathrm{C}$ temperature range," Solar Energy Materials and Solar Cells, vol. 134, pp. 215-226, 2015. 


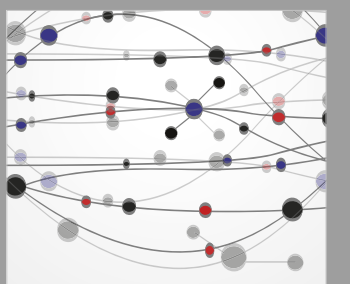

The Scientific World Journal
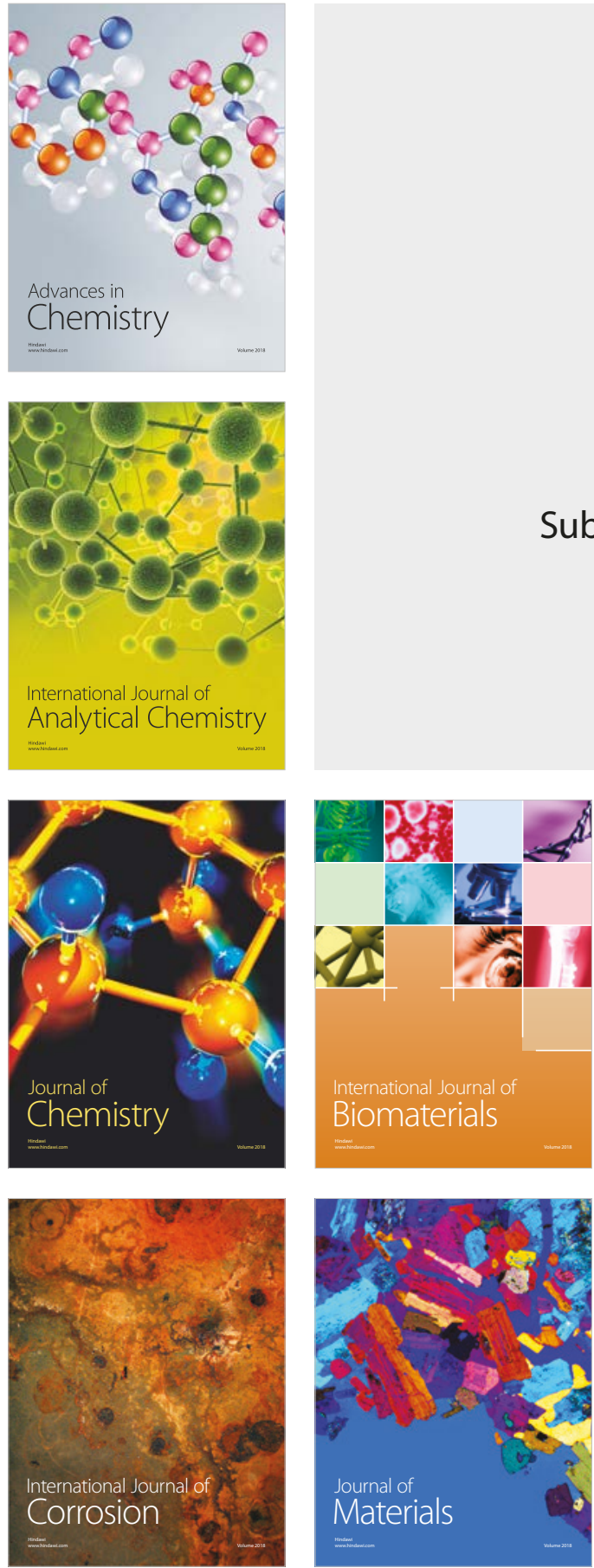

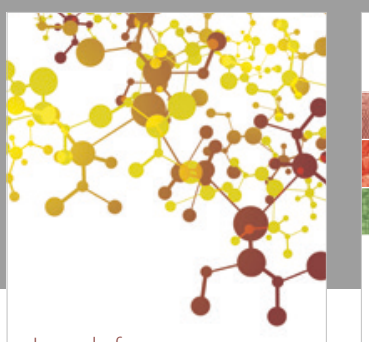

Journal of

Applied Chemistry
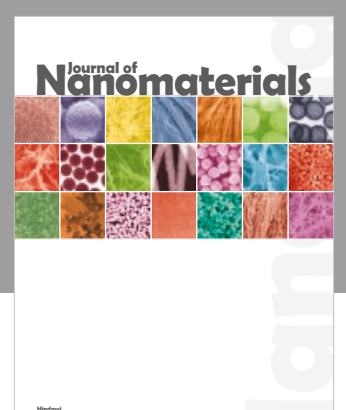

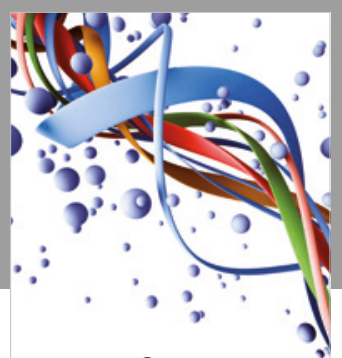

Scientifica

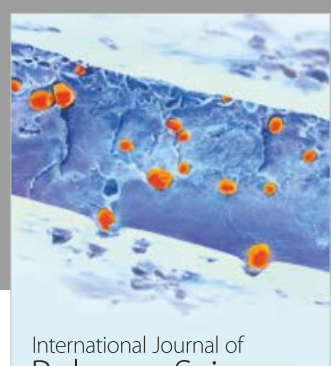

Polymer Science

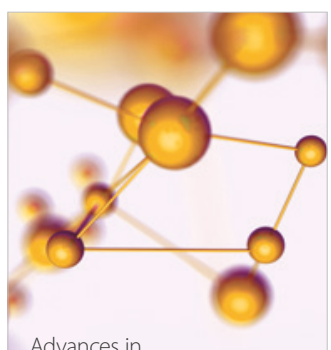

Physical Chemistry
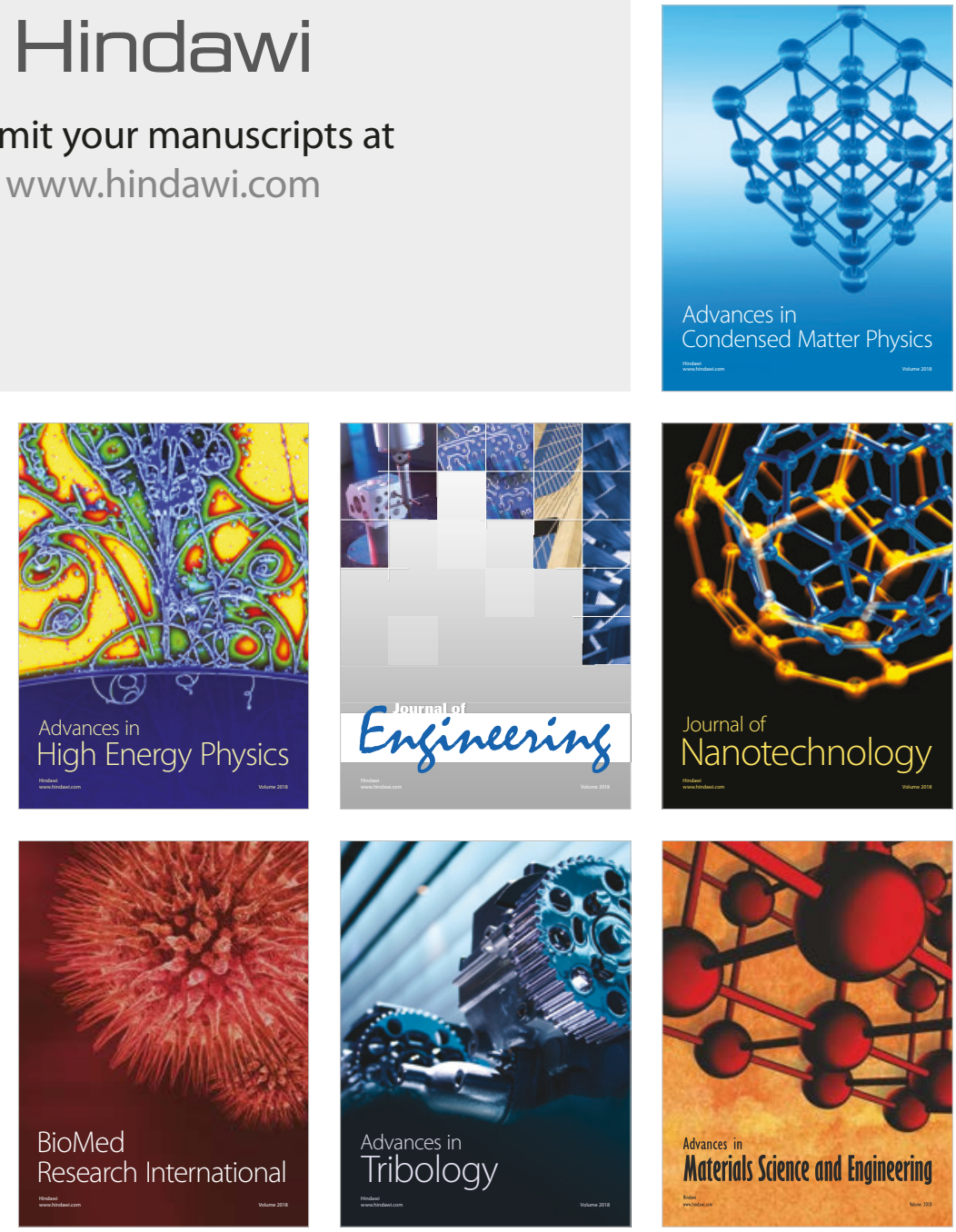